\title{
FUTURE-PROOFING ADULT LEARNING SYSTEMS IN CITIES AND REGIONS
}

A POLICY MANUAL FOR LOCAL GOVERNMENTS

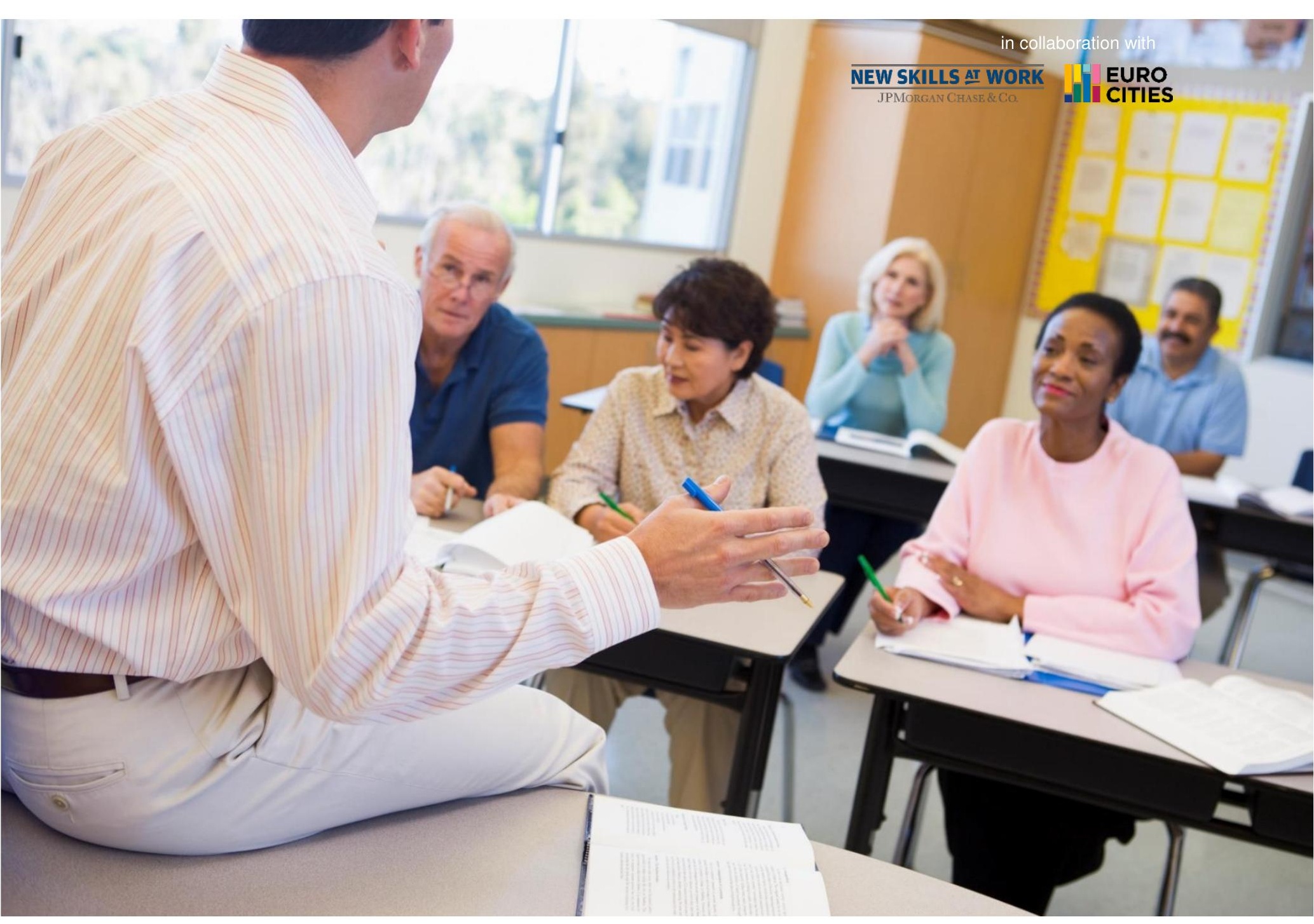

이 $O E C D$ 


\section{THE ORGANISATION FOR ECONOMIC CO-OPERATION AND DEVELOPMENT (OECD)}

The OECD is a multi-disciplinary inter-governmental organisation of 38 Member countries which engages in its work an increasing number of non-Members from all regions of the world. The Organisation's core mission today is to help governments work together towards a stronger, cleaner, and fairer global economy. Through its network of 250 substantive committees and their subsidiary bodies, the OECD provides a setting where governments compare policy experiences, seek answers to common problems, identify good practice, and co-ordinate domestic and international policies. More information is available at www.oecd.org.

\section{ABOUT OECD LOCAL ECONOMIC AND EMPLOYMENT DEVELOPMENT (LEED) PAPERS}

The OECD Local Economic and Employment Development (LEED) Programme Papers present innovative ideas and practical examples on how to boost local development and job creation. A wide range of topics are addressed, such as employment and skills; entrepreneurship; the social economy and social innovation; culture; and local capacity building, among others. The series highlights in particular policies to support disadvantaged places and people, such as the low skilled, the unemployed, migrants, youth and seniors.

This paper is published under the responsibility of the Secretary-General of the OECD. The opinions expressed and the arguments employed herein do not necessarily reflect the official views of OECD member countries.

This paper was authorised for publication by Lamia Kamal-Chaoui, Director, Centre for Entrepreneurship, SMEs, Regions and Cities, OECD.

The views expressed in this report should not be taken to reflect the official position of the JPMorgan Chase Foundation, JPMorgan Chase \& Co. or any of its affiliates.

Cover image: @getty/monkeybusinessimages

Images credit: p.12 @getty/monkeybusinessimages; p.16 @getty/fizkes; p.20 @getty/Halfpoint; p.25 @getty/Mukhina1; p.27 @getty/SeventyFour; p.32 @getty/Highwaystarz-Photography; p.36 @getty/LeoWolfert; p.40 @getty/Photo_Concepts; p.44 @getty/kzenon; p.48 @getty/howtogoto; p.52 @getty/ metamorworks; p.56 @getty/sqback; p.60 @getty/SIphotography.

\section{(c) OECD 2022}

This document, as well as any statistical data and map included herein, are without prejudice to the status of or sovereignty over any territory, to the delimitation of international frontiers and boundaries and to the name of any territory, city or area.

You can copy, download or print OECD content for your own use, and you can include excerpts from OECD publications, databases and multimedia products in your own documents, presentations, blogs, websites and teaching materials, provided that suitable acknowledgement of OECD as source and copyright owner is given. All requests for public or commercial use and translation rights should be submitted to rights@oecd.org 


\section{FUTURE-PROOFING ADULT \\ LEARNING SYSTEMS IN CITIES AND REGIONS}

A POLICY MANUAL FOR LOCAL GOVERNMENTS 



\section{Foreword}

In the coming years, labour markets will face significant challenges. There will be long-term economic, social and health consequences of the COVID-19 pandemic. In addition, ongoing structural changes including automation and digitalisation, demographic changes and the transition to a "green" economy will continue.

In this context, re- and upskilling of adults is an urgent priority for all at national, regional and local levels. To turn challenges into opportunities and to ensure that the supply of local skills matches constantly changing skills demands, there is a need to create strong adult learning systems for a more resilient and empowered society and productive economy. Future-ready adult learning systems should provide clear reand upskilling pathways for all individuals in need of training. This is especially important for groups that have a weaker attachment to the labour market such as the low-skilled, workers on non-standard contracts, long-term unemployed, individuals with a migration background, and youth not in employment, education or training.

Local governments have a critical role to play. As the level of government closest to citizens, they are well-placed to identify challenges faced by employers in the labour market as well as by workers falling through the cracks, which can vary significantly by locality. Indeed, current and potential workers, as well as employers, typically look for jobs and training opportunities in their neighbourhoods.

In addition, local governments can create a strong culture of adult learning that is effectively tailored to local needs, challenges and opportunities - a culture that is difficult to create through national initiatives alone. While there is growing awareness of this role, and many countries are decentralising responsibilities including those of adult learning, local governments still do not necessarily have the means and competences to respond to medium- and long-term needs.

To support local governments in their efforts to future-proof adult learning systems, this policy manual presents a range of policy options and concrete actions that can inspire and guide work at the local level. It is designed for both policy makers and practitioners at the local and regional level, but also for national policy makers to support their efforts in supporting the diversity of local needs.

The manual builds on three workshops held mid-2021 with over 60 cities, partnerships, business organisations, training providers and educational institutions, as well as a survey completed by 32 cities and regions with support from Eurocities and the European Committee of the Regions, along with additional research.

It has been developed as part of the OECD Local Employment and Economic Development (LEED) Programme. Created in 1982, the LEED Programme aims to contribute to the creation of more and better jobs for more productive and inclusive economies. 


\section{Acknowledgements}

This policy manual was prepared by the OECD Centre for Entrepreneurship, SMEs, Regions and Cities led by Lamia Kamal-Chaoui, Director, as part of the OECD's Local Employment and Economic Development (LEED) Programme, with financial support from the JPMorgan Chase Foundation.

The analysis and preparation of the policy manual were co-ordinated by Tilde Marie Ussing, Policy Analyst, under the supervision of Karen Maguire, Head of the Local Employment, Skills and Social Innovation Division, OECD. The policy manual was drafted by Tilde Marie Ussing and benefited from valuable comments and contributions from Kristine Langenbucher, Jonathan Barr, Anna Rubin, Lukas KleineRueschkamp, Tahsin Mehdi, Lars Ludolph, Francois Iglesias, Adriana Roldan Serrano and Miriam Odonkor (all present or former staff at the OECD Centre for Entrepreneurship, SMEs, Regions and Cities). Elisa Campestrin prepared the policy manual for publication.

The OECD Secretariat expresses its gratitude to various representatives from city and regional administrations who have been engaged in the development of the policy manual, including through participation in the OECD survey on adult learning in cities and regions and related workshops that have been organised as a part of the development of the policy manual in mid-2021.

The OECD Secretariat is grateful to the representatives from Eurocities, in particular Rossella Nicoletta, Nikita Sanaullah, Claudia Fernández Cuñado and Aleksandra Olejnik, for supporting the organisation of the survey and workshops, and for providing helpful comments on the development of the policy manual. Special thanks are also extended to Hanka Boldemann, Executive Director, Global Philanthropy at J.P. Morgan, for her comments and participation in the process. 


\section{Table of contents}

Foreword $\quad 5$

$\begin{array}{ll}\text { Acknowledgements } & 6\end{array}$

Introduction 9

Global labour market changes and the role of adult learning 9 The role of local governments in creating a culture of lifelong learning $\quad 10$

The structure of the policy manual 11

Promoting inclusion and equality through adult learning 13 In brief 13

Why is it important? $\quad 14$

$\begin{array}{ll}\text { Key policy areas and actions } & 16\end{array}$

Getting employers on board and meeting local skills demand

In brief

Why is it important?

Key policy areas and actions $\quad 36$

Creating strong local skills ecosystems $\quad 49$

In brief 49

Why is it important? $\quad 50$

Key policy areas and actions $\quad 52$

$\begin{array}{ll}\text { References } & 63\end{array}$ 


\section{Key definitions}

For the purpose of this policy manual, adult learning is defined as follows (OECD, 2001 [1]; Werquin, 2010[2]; OECD, 2019[3]; OECD, 2019 ${ }_{[4]}$;:

- Adult learning refers to adult education and training that is job-related and is expected to have a positive effect on performance and productivity at work.

- Adult learning includes three different types of education and training: 1) formal education and training, which leads to a formal qualification; 2) non-formal education and training that does not necessarily lead to formal qualifications, such as structured on-the-job training, open and distance education, courses and private lessons, seminars and workshops; and 3) informal learning, i.e. unstructured on-the-job learning, learning by doing or learning from colleagues.

- Adult learners are defined as individuals aged $25+$ years who have left the initial, "first chance" education system (either primary, secondary, post-secondary or tertiary level) but are engaged in learning.

- Adult learning systems encompass all the different institutions and individuals, as well as policies, laws and regulations concerned with the development and use of adult skills in the economy. An adult learning system is limited to a specific geographic area such as a country, region or city. 


\section{Introduction}

\section{Global labour market changes and the role of adult learning}

Labour markets across the world are changing due to population ageing, increasingly rapid digitalisation and automation, evolving supply chain dynamics and the green transition. These ongoing global megatrends are transforming the type of jobs available and the skills required to perform them. Such trends have an uneven impact across cities, regions and business sectors. While some places are experiencing significant job losses and transformations, others are characterised by innovation and growth, resulting in the creation of new types of jobs. In both cases, new and different skill sets are required.

With the COVID-19 crisis, many of the ongoing labour market changes are accelerating. Digitalisation and automation have picked up speed due to social distancing requirements as well as changing work habits and preferences. The green transition has gained even more momentum from stimulus packages as government commitments to tackle climate change take effect, with international agendas such as the United Nations' Sustainable Development Goals and summits on climate change (the COPs) prompting action, as well as often more ambitious local targets.

In this context of rapidly changing labour markets, adult learning systems are increasingly important. The extent to which individuals, firms and local economies can reap the benefits of ongoing changes and minimise the negative impact on workers will largely depend on the readiness of local adult learning systems. These systems foster lifelong skills development, enabling societies to help people develop and maintain relevant skills throughout their working life and to prepare them for changes that occur with the future of work. Many such systems target the unemployed, but there is a need to reach workers before they become unemployed.

Today, adult learning systems face multiple challenges:

- Inclusion and equality: Only two in five adults across the OECD participate in education and training in any given year. However, compared to lowskilled workers, medium-skilled workers are twice as likely to particulate in training, and high-skilled three times as likely. Those groups who most need to engage in adult learning - including low-skilled workers, migrants and long-term unemployed - often do not have access to or lack the time and resources to participate. They also may not have the right information or incentives about where to go and for what kinds of skills.

- Getting employers on board and meeting changing skills demand: Due to the rapid changes in labour markets, governments are struggling to make their adult learning systems more responsive to new skills demands. Employers also need to invest more in upskilling and reskilling their own workers, and developing the pipeline of future workers. The task is not only to produce more or better skills but also to produce the right skills to meet the specific needs of local employers now and in the future. 
Creating strong local skills ecosystems: While the organisation of adult learning systems differs significantly across OECD countries, a common feature is their complexity and fragmentation with regard to who is involved and their different responsibilities, which can lead to inefficiencies. Addressing this challenge requires strong relationships among employers, learning and training providers, local governments and social partners. It also benefits from greater co-ordination across different levels of government on learning and skills relevant for the labour market. A local strategy that brings everyone to the table, with sufficient financial means, will be needed to confront the challenges ahead.

\section{The role of local governments in creating a culture of lifelong learning}

Local governments are stepping up their efforts to make local economies more resilient and future-ready. The consequences of changing skills needs are felt acutely at the local level, through skills mismatches and skills shortages as well as the displacement of workers without the skills sought by their employers. This is why, as part of their efforts to make local economies more resilient, many cities and regions are engaging in efforts to improve adult learning systems.

Policies, regulations and funding for adult education and training are typically managed at the national level, yet needs can vary widely on the local level. Because skills needs differ across regions and local areas, national efforts can also only go so far in changing learning habits. There are many reasons why local governments can make a difference in the development of future-ready adult learning systems:

- Understanding local skills demand: Differences in local industry structures translate into differences in current and future skills requirements across local labour markets. National skills analyses may not always capture or prioritise what matters most locally. Local governments are typically in a better position to understand, and when possible respond to, the immediate needs and consequences of labour market transitions for their local area.

- Cultivating/Promoting inclusive cultures of lifelong learning: The community-based nature of many forms of adult learning often makes it possible to integrate learning elements in locally-led community activities. There are different ways to participate in formal, non-formal and informal learning opportunities. Local governments can work with small and mediumsized enterprises to raise awareness of the needs and opportunities. Local social economy actors such as non-profits may be providing opportunities to develop job readiness skills among those who struggle with traditional ways of learning.

- Strategically tailoring needs and bridging gaps: Local governments can draw on their proximity to the many actors involved in the planning and delivery of education and training, including training providers and employers, to bring some order to the otherwise fragmented adult learning systems. They can also fill gaps, in particular for those most in need. 


\section{The structure of the policy manual}

\section{Promoting inclusion and equality through adult learning}

Key policy areas

1. Target information and career guidance to local needs and groups

2. Adapt the format, content and eligibility criteria to local needs

3. Dedicate financing within local budgets

4. Integrate local services and engage social economy actors
Actions

1.1 Simplify access to information and career guidance through local channels

1.2 Develop easily accessible digital career guidance tools

1.3 Provide personalised career development guidance

1.4 Work with local stakeholders to provide targeted career guidance

2.1 Establish programmes targeted to specific group needs in the local area

2.2 Develop alternative forms of learning through community-based activities

2.3 Use flexible forms of formal, non-formal and informal learning 2.4 Ensure sufficient provision of basic skills programmes

3.1 Devote resources to raising awareness of learning opportunities

3.2 Use financial incentives to encourage provision of, and participation in, learning

4.1 Establish integrated models of service delivery

4.2 Work with the social economy to deliver education and training

\section{Getting employers on board and meeting local skills demand}

Key policy area

1. Get the data right - assess local skills supply and demand

2. Implement measures to match supply with demand

3. More actively engage employers in skills provision

\section{Actions}

1.1 Make strategic use of skills assessment and anticipation exercises 1.2 Consider targeted local skills assessment and anticipation exercises

2.1 Adjust the provision and content of learning offers to growing sectors 2.2 Provide incentives and information to guide learning choices

3.1 Provide targeted support to local SMEs and entrepreneurs

3.2 Build strong local leadership and partnerships with employer

Creating strong local skills ecosystems

Key policy areas

1. Improve co-ordination with higher levels of government

2. Strengthen co-ordination with local actors

3. Develop coherent financing models at all levels of government

\section{Actions}

1.1 Develop partnerships across different levels of government 1.2 Establish formal boards bringing together different levels of government 1.3 Engage in dialogue with national government on new competences

2.1 Engage private actors in local skills partnerships 2.2 Work with neighbouring municipalities

3.1 Negotiate flexible financing arrangements with higher levels of government 3.2 Develop local skills financing pacts between local stakeholders 



\section{Promoting inclusion and equality through adult learning}

\section{In brief}

Some groups are more at risk of experiencing job losses and long-term unemployment (or inactivity) due to changing skills requirements. These groups include among others migrants, youth, parents with young children, the elderly, long-term unemployed and persons with disabilities, which all tend to include larger shares of low-skilled workers with a weaker attachment to the labour market. Increasingly, many other types of workers are at risk of job displacement due to outdated skills. As in previous downturns, the COVID-19 crisis has disproportionally affected these groups, thus exacerbating pre-existing inequalities in labour markets.

Despite their obvious need for training, groups with weaker attachment to the labour market continue to be less likely to participate in adult learning programmes. Significant gaps in participation exist between high- and low-skilled workers, for example, and between workers with jobs at low or high risk of automation. Local governments therefore face a significant challenge to reduce barriers to participation for those groups most in need of re- and upskilling. They often need to step in and promote inclusion for groups at risk of getting left behind. These efforts also build resilience in the face of future labour market changes and thus contribute to local economic development more generally.

\section{Table 1. Key policy areas and actions}

Promoting inclusion and equality through adult learning

Key policy areas

1. Target information and career guidance to local needs and groups

2. Adapt the format, content and eligibility criteria to local needs

3. Dedicate financing within local budgets

4. Integrate local services and engage social economy actors
Actions

1.1 Simplify access to information and career guidance through local channels

1.2 Develop easily accessible digital career guidance tools

1.3 Provide personalised career development guidance

1.4 Work with local stakeholders to provide targeted career guidance

2.1 Establish programmes targeted to specific group needs in the local area

2.2 Develop alternative forms of learning through community-based activities

2.3 Use flexible forms of formal, non-formal and informal learning

2.4 Ensure sufficient provision of basic skills programmes

3.1 Devote resources to raising awareness of learning opportunities

3.2 Use financial incentives to encourage provision of, and participation in, learning

4.1 Establish integrated models of service delivery

4.2 Work with the social economy to deliver education and training 


\section{Why is it important?}

The pandemic exacerbates already polarised labour markets in many cities and regions. While the ongoing changes to skills requirements have the potential to affect all workers, automation and digitalisation are skill-biased technologies that favour high-skilled workers at the expense of middle- and low-skilled workers (OECD, 2018[7]). Especially vulnerable are workers in jobs that are characterised by simple and repetitive tasks. They are likely to bear the brunt of these changes, calling for more training to maintain labour market attachment (Box 1).

\section{Box 1. Which groups in cities and regions are especially vulnerable to future labour} market changes?

In the context of adult learning, some groups are at higher risk of getting left behind, because they have - or risk having - weaker attachment to the labour market and are in need of training and education for a stronger and sustainable labour market attachment. Weaker attachment may be the result of their specific characteristics or because they are being discriminated against, which adds to the challenge of finding work. Evidence from across OECD countries shows that these groups tend to include low-skilled or low wage workers, women with young children, youth, single parents, elderly, migrants, indigenous people, people who experience a disability, displaced, (long-term) unemployed, workers in nonstandard jobs and SME workers (OECD/European Union, 2019 $9_{[8]}$; OECD, 2020[9]; OECD, $\left.2021_{[10]}\right)$. Some groups, including low-skilled workers and youth, are more vulnerable to shortterm job losses as they are highly represented in sectors most at risk from COVID-19 (Berube and Bateman, 2020[5]) and are more likely to be on temporary contracts in general (OECD, $\left.2014_{[6]}\right)$. Importantly, far from all individuals that fall within these groups are per se vulnerable and it is usually a combination of factors that increase the risk of having weaker labour market attachment.

Despite their need for education and training, evidence shows that groups with weaker attachment to the labour market tend to be underrepresented in adult learning. The largest average gaps are found between the low- and medium/highskilled workers and between adults in jobs at high and low risk of automation. Only around $20 \%$ of adults with low skills participate in adult learning, while the participation rate for adults with medium and high skills is significantly higher $(37 \%$ and 58\% respectively) (Figure 1) (OECD, 2019[11]).

The OECD survey on adult learning in cities and regions shows that the inclusion of vulnerable groups is a challenge faced by many local governments. A majority of participating cities and regions reported that the inclusion of vulnerable groups is the key challenge facing their adult learning system (Figure 2). The groups that face the most pressing need for adult learning and education are the unemployed, migrants and low-skilled and/or low-paid workers.

Supporting vulnerable groups to re- and upskill is important not only for the individual but also for societies more generally. Through participation in adult learning, vulnerable groups may increase their employability, and thus their chances of gaining or maintaining labour market attachment, and ultimately their social inclusion (Cedefop, 2017 $[12])$. At the same time, local employers may benefit from a 
more qualified and innovative labour force, which may positively influence productivity and thus local growth (European Commission, 2015 [13]).

Figure 1. Participation in job-related training by group, OECD average

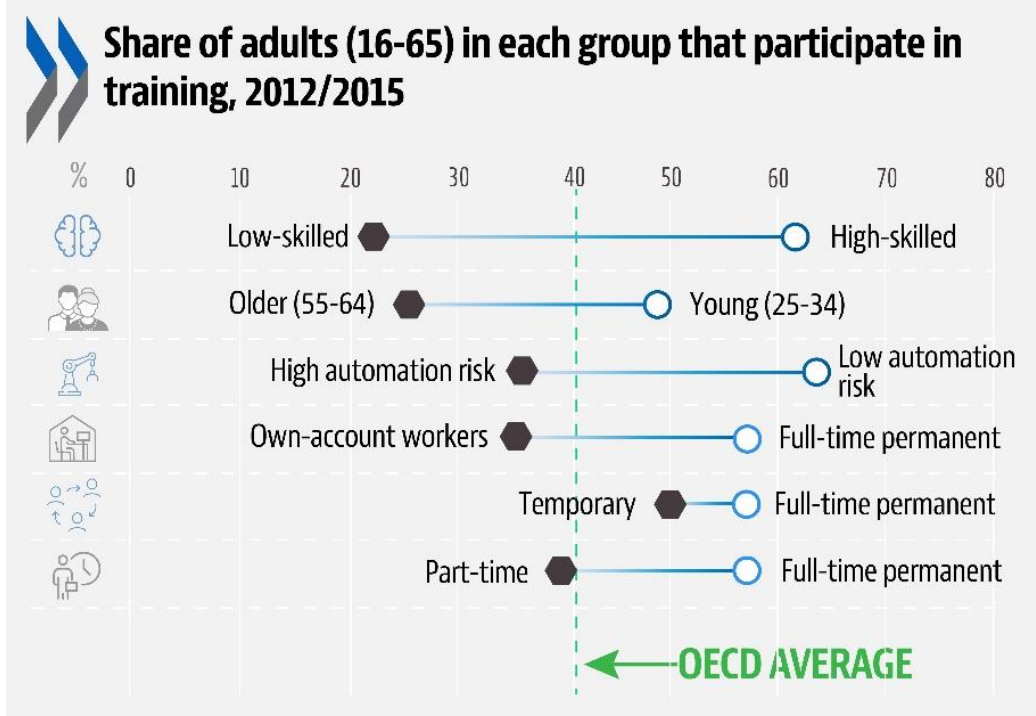

Note: Share of adults who participated in formal or non-formal job-related training over the previous 12 months. High (low) automation risk refers to adults at high (low) risk of automation. Own-account workers are the selfemployed without employees. Temporary refers to workers on fixed term or temporary work agency contracts. Part-time refers to adults who work less than 30 hours per week. Full-time permanent are adults in full-time jobs with an indefinite work contract. The OECD average $(41 \%)$ refers to the unweighted average participation in jobrelated training among all adults among OECD countries participating in the Survey for Adult Skills (PIAAC). Data refer to 2012 for most countries, except for Chile, Greece, Israel, Lithuania, New Zealand, Slovenia and Turkey where they refer to 2015.

Source: (OECD, 2019[14]). Survey of Adult Skills (PIAAC) (2012, 2015), http://www.oecd.org/skills/piaacl.

\section{Figure 2. The most pressing challenge facing cities' and regions' adult learning systems}

\section{What is the most pressing challenge facing your city's or region's adult learning system?}

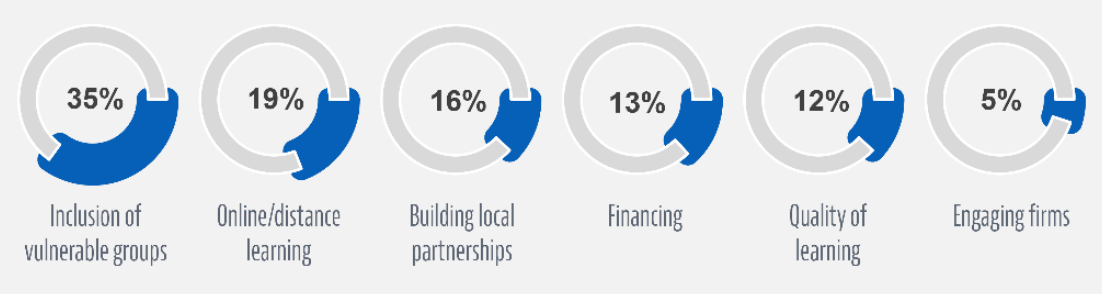

Note: Participating cities and regions have answered the question "What is the most pressing challenge facing your city's adult learning system?"

Source: OECD/Eurocities survey on adult learning systems in cities and regions, 2021. 


\section{Key policy areas and actions}

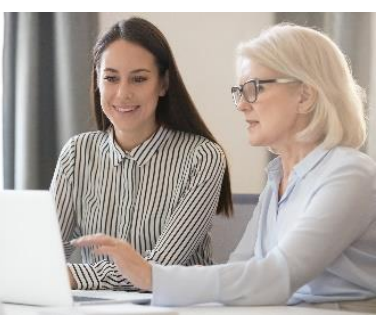

\section{Key policy area 1: Target information and career guidance to local needs and groups}

Career guidance is a fundamental policy lever to help individuals successfully navigate a constantly evolving labour market. Through career guidance, individuals may get help in identifying their training needs, understanding which type of training they can benefit from, and navigating the many offers available (Box 2). Career guidance has been crucial not least during the COVID-19 pandemic, where it has helped facilitate re-employment for laid-off workers by identifying new job opportunities and proposing relevant training (OECD, 2021 $\left.{ }_{[15]}\right)$.

\section{Box 2. What is career guidance, is it delivered by cities and regions, and does it work?}

Career guidance may be defined as services intended to assist individuals to make wellinformed educational, training and occupational choices. When effective, career guidance can help individuals become aware of available training and employment opportunities, reflect on their strengths and interests, empower them to make better decisions about their lifelong career development and help them get closer to (re-)entering the labour market. The survey on adult learning in cities and regions shows that $30 \%$ of cities and regions have responsibilities either for the provision of career guidance or the provision of information and communication. The guidance may be delivered either by local public authorities or in cooperation with other actors such as public employment services (PES), private providers, educational institutions and companies. Services may be targeted to particular groups or they may be open to anyone.

Source: (OECD, 2004 $\left.4_{[16]}\right)$; OECD/Eurocities survey on adult learning in cities and regions, 2021.

Many of the groups who face disadvantages in the labour market, including the low-skilled, use career guidance services less often than the reference population. In addition, of those adults who do not use career guidance services, most do not feel they need to $(57 \%)\left(\right.$ OECD, $\left.2021_{[15]}\right)$. Often, these groups do not recognise their own learning needs or their skills gaps and they find it difficult to access relevant information in the jungle of programmes (Windisch, 2015[17]). To overcome this challenge, local governments can, within their local competences, use different measures to target information and career guidance to those most in need.

\section{$\stackrel{5}{=}$ Action 1.1. Simplify access to information and career guidance through local channels}

One way to increase the use of career guidance among groups with weaker attachment to the labour market is to make it more easily accessible. As the public body closest to these groups, local governments play a crucial role in simplifying access to information and career guidance. One way to do so is to set up local lifelong learning centres, where all information on adult learning and training as well as access to career guidance is gathered in one physical place. This makes it easier for individuals to access and find the programme or guidance that is right for 
them. Setting up lifelong learning centres, however, requires that all local public authorities involved in the provision of adult learning policies work together across different administrative systems to provide a coherent offer to citizens.

Another way to ensure that information and career guidance is provided to the groups most in need is through mobile outreach services that are accessible for hard-to-reach groups and places. Often, career guidance is concentrated in the bigger cities or in certain parts of cities or regions, which does not always match where the hard-to-reach groups live or frequent on a regular basis. Due to time and financial costs associated with transportation, this may pose a barrier to participation for certain groups. Mobile outreach services e.g. in the form of physical vans driving around the city or temporary "offices" in local libraries, schools, workplaces or other community areas, can be used by local governments to increase access to career guidance. One example of how to provide career guidance services in more challenged neighbourhoods is the Neighbourhood Employment Hubs in Michigan, the United States (Box 3).

\section{Box 3. Neighbourhood Employment Hubs in Michigan (the United States)}

Through a collaboration with neighbourhood organisations and community partners, Michigan Works! Southwest is striving to serve the neighbourhoods with the highest poverty and unemployment rates. The programme aims to bring individuals above the poverty level by removing barriers to finding employment for individuals who typically do not access mainstream services. The Employment Hubs are outreach service stations providing customised employment and career guidance services to individuals in their neighbourhood with employment specialists dedicated to providing guidance and support. The Hubs are strategically co-located with three other neighbourhood organisations throughout diverse neighbourhoods so to best reach those individuals that the programme aims to serve. In collaboration with Kellogg Community College, Michigan Works! Southwest refers suitable individuals to training in fields that will result in employment. In addition, they work with the county jail to provide services to individuals prior to release, assisting in a successful transition to community life. The project is financed through a three-year grant from the W.K. Kellogg Foundation.

Source: (Michigan Works! Southwest, 2021 ${ }_{[18]}$ )

\section{Action 1.2 Develop easily accessible digital career quidance tools}

For some groups, information and career guidance may be most easily accessed through online channels. Through targeted, easily accessible online career guidance tools, local governments might better reach youth entering the labour market for the first time, for example. The development of targeted online tools, however, often requires significant resources and specialised knowledge to make them up to date and useful for individuals seeking to engage in adult learning. Therefore, local governments may collaborate with local businesses, universities and other stakeholders to gather the necessary resources and insights (see section 1.5). This is exactly what they have done in Greater Manchester in the United Kingdom (Box 4). Importantly, to enable the inclusion of other groups characterised 
by low digital skills or limited access to internet/computers, local governments must ensure that alternative services are available offline.

\section{Box 4. Greater Manchester's Work and Skills Ecosystem (the United Kingdom)}

Greater Manchester Combined Authority (GMCA) is developing a work and skills ecosystem with the aim of supporting young people and adults to gain the relevant skills and knowledge to get into employment, sustain their jobs, and progress in their careers. The main objective of the programme is to create an integrated employment and skills ecosystem, which has the individual and employer at its heart, responding to the needs of the residents and businesses in the city and contributing to local economic development and growth. The programme includes the Bridge programme, which aims to bring together businesses, education leaders and career professionals, to develop a career programme for young people. There are several initiatives under the Bridge programme, one of which is Start. Start is a career guidance software, connected to live labour market information and course data, to help young people make informed career decisions. Users can create a personal profile that generates relevant jobs, qualifications and new paths to explore. Over 3500 young people are actively using the tool at no charge and it is available to schools, colleges and parents as well. Through the tool, young people are able to understand themselves, their skills and interests, as they build their profiles, and they are able to explore suitable career pathways. Start also has Track, which enables other stakeholders to analyse the data their students are inputting into the system, so that they can support and guide them to develop their skills and talents.

Source: (GMCA, 2021 ${ }_{[19])}$. For more information go to Future-proofing Adult Skills Systems in Cities: Case Studies - OECD.

\section{Action 1.3 Provide personalised career development guidance}

For career guidance to be effective, its content must be adjusted to the specific needs of the individuals that participate. Through their connections to local education providers and businesses, local governments are in a good position to provide individualised support responding to the needs of individuals as well as the local economy. Local governments may use different measures to individualise guidance, including through dedicated personal employment and training advisors that provide individuals with targeted advice or individual career roadmaps that lay out the individual's journey through the training and employment system. A recent survey has shown that receiving a personalised career development roadmap as well as face-to-face provision of career guidance makes a positive difference to employment outcomes (OECD, 2021 [15]).

Dedicated personal advisors often have to support individuals in many different ways across different professional areas (education, employment, health, etc.). Therefore, a challenge in the implementation may be that local governments need to invest in the training of public officials to be able to offer individualised support, especially for those furthest away from the labour market. In Donegal, Ireland, they have experience with the use of dedicated personal employment advisors to support women (re)entering the labour market (Box 5). 


\section{Box 5. Training and Confidence Building for Women in Donegal (Ireland)}

In Donegal, Ireland, the Women's Integration Skills and Employment (WISE) project was implemented to help women who are furthest from the labour market to regain employment, undertake training or become self-employed. The project was implemented in the Donegal county of Ireland from May 2017 to April 2020. The project, cofunded by the European Social Fund (ESF) and the Department of Justice and Equality in Ireland, provided free services to equip women of all ages with the skills and confidence needed to return to employment and earn a living. As part of the WISE project, all participants were assigned a dedicated personal employment advisor free of charge. These advisors supported the participants in practical areas such as writing CVs, improving their interview skills and understanding employment contracts. The advisors also guided them on accessing suitable training programmes and educational opportunities and on becoming self-employed. Furthermore, the WISE team motivated and built confidence in the participants as (re)entering the labour force is a source of anxiety for some. In addition to personal services, the team assessed the abilities and interests of participants and subsequently screened positions with local employers to find a match between job opportunities and the participants' profiles. The team also supported participants after they were employed for up to six months and assisted them in getting public funding related to issues such as training and childcare support.

Source: (European Commission, 2021[20]). For more information go to Future-proofing Adult Skills Systems in Cities: Case Studies - OECD.

Action 1.4 Work with local stakeholders to provide targeted career guidance

Yet another way of targeting career guidance is to link it more directly to the many local stakeholders involved in adult learning. By engaging other stakeholders such as learning providers, businesses and civil society, local governments might ensure the provision of alternative and innovative forms of guidance - e.g. in the workplace or in training institutions. As an example, recent evidence from OECD countries shows that career guidance provided by employers or employer associations is linked to positive employment outcomes (OECD, $\left.2021_{[15]}\right)$. However, when engaging non-public bodies in the provision of career guidance, local governments must be aware that guidance is still made available for all groups including those furthest away from the labour market. In Greater Toronto, Canada, the city is co-operating with the not-for-profit movement United Way Greater Toronto to provide career guidance for young people, and in Rotterdam, the Netherlands, the city has developed the BRIDGE Project to provide career guidance for students in close co-operation with local employers (Box 6). 
Figure 3. The willingness to train by group, OECD average

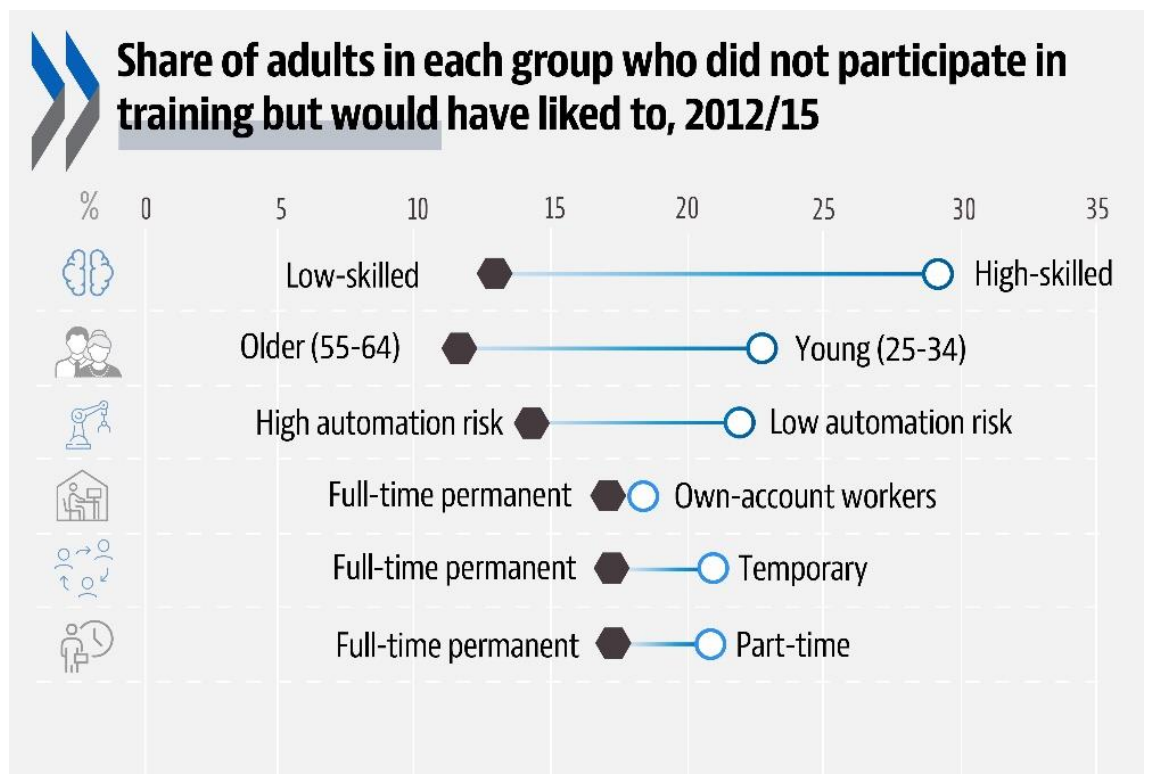

Note: Share of adults who did not participate in training but report that, over the previous 12 months, there were learning activities that they would have wanted to participate in. Low (high) skilled refers to adults who score at level 1 or below (levels 4 or 5) on the PIAAC literacy scale. High (low) automation refers to adults at high (low) risk of automation. Own account workers are the self-employed without employees. Temporary refers to workers on fixed term or temporary work agency contracts. Part-time refers to adults who work less than 30 hours per week. Full-time permanent are adults in full-time jobs with an indefinite work contract. Data refer to 2012 for most countries, except for Chile, Greece, Israel, Lithuania, New Zealand, Slovenia and Turkey where they refer to 2015. Source: (OECD, 2019[14]). Survey of Adult Skills (PIAAC) $(2012,2015)$, http://www.oecd.org/skills/piaac/.

Local governments may overcome these challenges through targeted measures that directly reach out to those adults who face additional barriers to participation. Due to their closeness to local stakeholders and target groups, local governments may be in a better position to target the format, content and eligibility criteria of programmes so as to match the needs of those most in need.

\section{Action 2.1 Establish programmes targeted to specific group needs in the local area}

One way to overcome the low willingness to train is through the provision of targeted adult learning programmes that take into account the specific characteristics and learning needs of certain groups. Across local governments, it is common to provide adult learning programmes that cover different skill sets (e.g. digital, green or health skills) or occupations (e.g. computer programmer, windmill engineer or nurse). Yet, to reach certain groups such as migrants, youth or lowskilled workers, it can also be relevant to provide programmes that are specifically targeted to these groups.

To make the targeting effective it should be data-driven to identify groups for whom targeted measures may be relevant and based on evaluations on what works. For example, the Move In, Move On, Move Up (MIMOMU) programme in Bristol, the United Kingdom, delivers targeted training for homeless people in the city, while the city of Munich, Germany, provides targeted training programmes for newly arrived migrants and refugees (Box 7). 


\section{Box 7. The Bristol MIMOMU programme (the United Kingdom)}

The Move In, Move On, Move Up (MIMOMU) programme in Bristol sets out to support homeless people in the city to access the local labour market through face-to-face services delivered by frontline workers across the city. The programme, running from August 2020 to March 2022, is funded in part by the National Department of Work and Pensions and in part by the Bristol City Council. The key objective of the programme is to produce a service offer that addresses the employment needs of the homeless community in the city and enables this group to grow their talents, overcome barriers and progress towards work. The support is delivered through a personalised service so that homeless individuals are supported to upskill with new experiences and qualifications, take part in job fairs and pop-up events across the city, build better relationships and networks, develop effective communication skills, and participate in geographic sector-based work academies. The core service is being delivered face-to-face by dedicated frontline workers offering language support, employability support, job coaching and wrap-around support, e.g. debt service, health service, tenancy, welfare rights and housing.

\section{Providing Adult Learning for Newly Arrived Migrants and Refugees in Munich (Germany)}

To support the integration of newly arrived migrants and refugees, the city of Munich offers individual educational profiling and targeted educational programmes from the first day of arrival in the city. The programme is based on the recognition that longer periods of labour market and social exclusion negatively effects individuals through a loss of vocational skills, social skills, self-confidence, motivation and re-traumatisation. Therefore, a key element of the programme is the emphasis placed on intensive psychosocial support. The programme starts with an individual profiling by a counselling centre based on which individual support needs are defined and the student is placed in various programmes (e.g. language courses, courses for basic education and school-leaving qualifications, courses to prepare for the labour market, and offers to support at the transition from school to employment). The programme follows a resource-oriented approach of empowerment, where the definition of learning goals takes into account the individual capacities of learners.

Source: OECD/Eurocities survey on adult learning systems in cities. For more information go to Future-proofing Adult Skills Systems in Cities: Case Studies - OECD.

Action 2.2 Develop alternative forms of learning through communitybased activities

Another way to get groups with weaker attachment to the labour market engaged in adult learning programmes is through the development of alternative forms of learning. Evidence shows that adults generally tend to learn best when learning is put into context and when it is practical and problem-oriented (Tough and Knowles, 1985[21]). This is especially true for vulnerable groups, as many of them have experienced failure in education and may find it difficult to return to a classroom setting. Therefore, training must have a format that allows them to learn in their own way e.g. through on-the-job training or by using music, sports and cultural activities as tools of learning. Establishing alternative forms of learning often requires innovative and creative thinking and strong partnerships with education providers, employers and other local actors that can provide learning in new settings, 
e.g. in the workplace, museums or local sport centres. A programme in Fuenlabrada in Madrid, Spain offers an example of how local governments can work with alternative forms of learning for groups at risk of getting left behind (Box 8).

\section{Box 8. Fuenlabrada's MILMA Project for Migrants (Spain)}

The MILMA (Migrants Labour Integration Model based on Acculturation) project in Fuenlabrada seeks to promote integration of people at risk of social exclusion, including migrants and unemployed in the local labour market. The project started in 2017 and is funded through the European Regional Development Fund (ERDF). The MILMA project is based on a collaborative model where local and migrant unemployed people work together to increase their employability and where employers, social economy actors and other local stakeholders are engaged in the training and education provision. A key element of the project is Business Challenges (BC) labs, which provide targeted training and alternative forms of learning to participants, specifically technical and practical skills in areas of employment with high demand for workers in the present or future (e.g. Green Production, Urban Creation and Recycling, Communication and Production, and Digital Production). The BC labs also promote entrepreneurship by encouraging interested participants to develop products and services to meet job market needs.

Source: (UIA, 2019 $\left.9_{[22]}\right)$ For more information go to Future-proofing Adult Skills Systems in Cities: Case Studies - OECD.

\section{Action 2.3 Use flexible forms of formal, non-formal and informal learning}

Another way to overcome the shortage of time barrier is through measures that allow individuals to participate in training in ways that are more flexible. This may include the possibility to participate in programmes on a part-time basis or during the day, evening or weekend. It may also include the use of modular and/or credit-based formats such as micro-credentials that address issues with time and motivation by dividing learning programmes into self-contained modules (Box 9). The provision of flexible forms of learning, however, also requires flexibility on the side of local governments and learning providers, e.g. to set up learning in the evenings or weekends. 


\section{Box 9. Micro-credentials - a new way for adults to re- and upskill?}

Micro-credentials - which may be defined as short, targeted and flexible non-degree learning programmes - are gaining increasing policy traction in many countries in the face of rapidly shifting skills demand. These shorter skills-focused courses are often stackable, relatively cheap and fast, and aligned to the specific needs of industries/employers, which makes them an easy way for individuals in the working age to re- and upskill to meet immediate skills gaps in the labour market. For some vulnerable groups experiencing difficulties with less flexible training courses, micro-credentials have the potential to encourage renewed engagement in education and training. However, for now, many micro-credential programmes are provided by higher education institutions and thus target individuals with higher skills levels and possibly stronger attachment to the labour market already. For micro-credentials to be a method to increase inclusion in adult education and training, governments and education providers must design programmes that specifically address groups at risk of weaker attachment to the labour market such as young people not in employment, education or training, and the long-term unemployed.

Source: (OECD, 2021 [23]; Kato, Galán-Muros and Weko, 2020[24]; Robson, 2022[25])

Flexible learning can also include the use of distance learning. Since the outbreak of the COVID-19 pandemic, many local governments have taken steps to introduce, expand and improve the online delivery of programmes. Online learning has the potential of delivering more affordable training, as the costs are relatively lower than face-to-face teaching and as many components of online course work are scalable $\left(O E C D, 2020_{[26]}\right)$. Especially for vulnerable groups, however, online learning may create new challenges. These groups often lack adequate digital skills or sufficient equipment to participate in or benefit from the online learning.

\section{Action 2.4 Ensure sufficient provision of basic skills programmes}

In Europe alone, an estimated $\mathbf{7 0}$ million adults lack adequate reading and writing skills, and even more have poor numeracy and digital skills (OECD, $\left.2019_{[4]}\right)$. Therefore, it is essential that local governments ensure a strong provision of basic skills programmes. A challenge in this regard may be for local governments to provide enough skills programmes to meet the needs of the many different groups of citizens. There are many interesting examples of basic skills programmes locally, including in Amsterdam, the Netherlands, where they are providing basic IT training in disadvantaged boroughs in the city (Box 10) 


\section{Box 10. "TechGrounds" in disadvantaged boroughs in Amsterdam (the Netherlands)}

In 2016, the City of Amsterdam opened the "TechGrounds" training centre in Nieuw-West, a disadvantaged borough in the city, to provide IT training for unemployed people with no or limited IT skills. Since then, more "TechGround" training centres have opened in other disadvantaged boroughs in the city. The "TechGround" project is a collaboration between the Amsterdam Economic Board and a range of other stakeholders, including the CA-ICT training fund and TomTom (a private tech company). The initiative brings together several companies, educational institutions and government organisations in Amsterdam. "Techground" is based on the philosophy of "learning to learn" and "peer learning," and functions as a "school without teachers". Learning is provided by "learning coaches" that help students find their own way through the system. During the training, participants are matched with tech entrepreneurs who become project partners. In addition to training, the centres also offer co-working spaces, organise tech events and house start-up incubators. "TechGrounds" are accessible to everyone (no requirements of preliminary education or diploma), free of charge.

Source: (Dimitrova, $\mathbf{2 0 1 9}_{[27]}$ ). For more information go to Future-proofing Adult Skills Systems in Cities: Case Studies $\underline{\mathrm{OECD}}$.

\section{Key policy area 3: Dedicate financing within local budgets}

Financial issues present one of the main obstacles preventing adults from taking part in adult learning activities. Within their competences, local governments may use financial measures to reduce barriers to participation directly by providing training at no or limited costs, or indirectly by covering related costs such as transportation, training equipment or lost income due to participation in training.

\section{Action 3.1 Devote resources to raising awareness of learning opportunities}

Financial incentives directed at individuals or employers may come in many forms, e.g. wage and training subsidies, training vouchers, tax incentives, loans and individualised learning account schemes (OECD, 2017[28]). Within their responsibilities and available resources, local governments may use financial incentives to reduce barriers to participation. An interesting example hereof is found in Rotterdam, the Netherlands, where the municipality is using training vouchers targeted residents who are facing economic challenges (Box 11). 


\section{Box 11. Rotterdam retrains jobseekers for the changing world of work (the Netherlands)}

In September 2020, the municipality of Rotterdam started giving out training vouchers to residents through the Rotterdam Schooling Fund project. These vouchers are intended to pay for courses and training in professional areas with high demand, given the changes brought about by the COVID-19 pandemic. As many businesses shut down during the pandemic, leading to job cuts, jobseekers and young people, who have limited qualifications, were most affected. In addition, certain industries such as the tourism and hospitality recorded high job losses due to social distancing measures. Conversely, industries such as healthcare, IT and technology were in urgent need of qualified people. Thus, the Rotterdam Schooling Fund seeks to connect those in need of jobs to sectors in need of personnel, by enabling jobseekers to gain relevant training and education. Rotterdam is targeting residents who are facing economic challenges, such as those who are jobless but are willing to work and learn, people who are on social security benefits and people whose unemployment benefits expire within three months. The measure also targets young people who have obtained pre-vocational education diplomas (called MBO diplomas) in sectors that have no jobs due to the COVID-19 pandemic. These groups of residents are given a voucher worth EUR 2500 for training.

Source: (theMayor.eu, 2020[29]). For more information go to Future-proofing Adult Skills Systems in Cities: Case Studies - OECD.

\section{Action 3.2 Use financial incentives to encourage provision of, and participation in, learning}

The demand for training has increased significantly in the context of the COVID-19 pandemic. In addition, the crisis has created a need for remote delivery of training, which has challenged adult learning systems in other ways, including a need to retrain trainers/educators and provide digital equipment for learners. In crisis situations like these, it might be necessary for local governments to implement shortterm investment packages to ensure sufficient provision of training and education. In Vienna, Austria, the municipality adopted a EUR 17 million education and training package directed towards young people in the city (Box 12).

\section{Box 12. Vienna (Austria) is providing education and training for young people}

The COVID pandemic has adversely affected young people, and the youth in Vienna are no exception. The number of unemployed young people in Vienna as at May 2020 was 172 646, which is a $57.2 \%$ increase as compared to May 2019. To address this challenge, the city authorities launched a EUR 17 million education and training package in June 2020, which the Vienna Employment Promotion Fund (waff) is implementing. The education and training package includes EUR 10 million for intra-company vocational apprenticeships and EUR 7 million for qualifications of young unemployed. The qualification covers qualification passports for educational screening of over 3000 young and unemployed, and assistance to continue with previously stalled apprenticeships and other training. Finally, the package covers qualifications for future professions in the healthcare, IT and other emerging sectors.

Source: (Eurocities, 2021 $\left.{ }_{[30]}\right)$. For more information go to Future-proofing Adult Skills Systems in Cities: Case Studies - OECD. 


\section{Key policy area 4: Integrate local services and engage social economy actors}

While adult learning is vital to improve labour market attachment among groups with weaker attachment to the labour market, additional support services may be necessary to reduce barriers to their participation in education and training. These groups often struggle with multiple disadvantages, which may require a range of services that cut across policy sectors. Beyond the need for re- and upskilling, these groups may need additional support or "wraparound services", including other forms of activation measures, social services, mental or physical health care, integration or housing support.

Responsibilities for these services tend to be divided between levels of government and often measures to ensure co-ordination are lacking. This makes it difficult for more vulnerable groups to access services and for practitioners to address the multiple underlying issues in a holistic way (OECD, 2015 $\left.{ }_{[31]}\right)$. The consequences are often felt at the local level where the responsibility for social policies to support those who are falling through the cracks of the system tend to lie.

\section{Action 4.1 Establish integrated models of service delivery}

To overcome problems of fragmentation and increase adult learning participation among more vulnerable groups, local governments may implement integrated models of service delivery. Integrated service delivery implies that adult learning programmes are provided in combination with other support measures such as housing support or social services. While evidence shows that there are many benefits from such integrated models, including increasing labour market attachment for vulnerable groups, there are also many possible barriers to integration - ranging from political reluctance to undergo changes to more practical difficulties in the implementation phase (e.g. making different professional cultures work together). Nevertheless, local governments across OECD countries are implementing integrated service models that cover adult education and training, including in London, the United Kingdom, Gdansk, Poland and Zaragoza, Spain (Box 13).

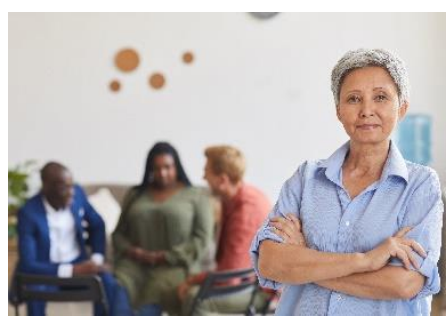




\section{Box 13. Integrated service models}

\section{The West London Skills Escalator (the United Kingdom)}

In 2014, the West London Alliance (on behalf of the London Boroughs of Hounslow and Harrow) developed the Skills Escalator, a personalised advice and skills acquisition support service for working people on low incomes to move into better-paid and more stable employment. The programme is ongoing and is funded by the London Borough of Ealing and the European Social Fund (ESF). The programme targets working people over 25 in the Borough living in council, privately rented or temporary accommodation, and receiving housing benefits. The programme offers residents an integrated support offer, including one-to-one support from an adviser structured around a personalised action plan, a core offer of referral to existing skills provision with the cost of provision covered by the service, wrap-around support from other existing services, including social, employment and housing services as well as employer engagement.

\section{So Stay Hotel Provides Training for Care Home Leavers in Gdansk (Poland)}

The Municipality of Gdansk established the So Stay Hotel to address the challenges of young people who face barriers in accessing education and vocational training in the public school system. The programme started in 2016 and is still in place. It was established with support from the Municipality of Gdansk, the Social Innovation Foundation and business partners. The hotel operates on an innovative model, which combines a market approach with social responsibility to support young people who grew up in care homes in gaining work qualification and experience through internships and job programmes in the hotel. In this way, the hotel invests in their education, creates internships and first workplaces. Participants learn from and are guided by professionals in the hotel, gaining relevant skills that enable them to gain employment outside the hotel. Moreover, in this holistic approach, the programme provides young people with housing support as they learn and earn income.

Source: (OECD, 2021 $\left.{ }_{[32]}\right)$. OECD/Eurocities survey on adult learning in cities and regions. For more information go to Futureproofing Adult Skills Systems in Cities: Case Studies - OECD.

An important way of providing learning through integrated service models is through non-formal adult education or community education. Non-formal and community-based education is education that takes place outside the formal education sector and which aims at enhancing learning, fostering empowerment and contributing to civic society. Often this type of training seeks to meet the needs of those who wish to access learning locally as a step to more active community involvement and certified learning. Community learning reaches those groups who are most difficult to engage in adult learning and includes a range of programmes such as on parenting, knitting, democratic education, community development and digital literacy. Often programmes are delivered as a holistic service, which means that individuals can access integrated support as part of their education programme, including financial advice, childcare, counselling, career guidance and transport. A challenge for non-formal adult education is the lack of validation systems to identify, document, assess and certify these types of learning and thus use them as a basis for getting into the labour market or participate in further education and training (European Association for the Education of Adults, 2021 [33]; Cedefop, European Commission and ICF, 2019 [34]]). Given their tight links with the local community, local 
governments play a critical role in supporting non-formal and community-based education and training. Box 14 provides an example of a community-based adult education centre in Dublin, Ireland, as well as the Irish Back to Education Initiative (BTEI), which provides financial support to youth and adults with little or no formal educational qualifications to take-up part-time education.

\section{Box 14. Non-formal and community-based education and training in Ireland}

\section{Back to Education Initiative}

The Irish Back to Education Initiative (BTEI) commenced in 2002 and provides flexible parttime further education to adults and young people aged over 16 who left school with few or no formal qualifications or low literacy levels. Through the part-time offer, it enables learning for adults who need to balance their return to education with family, work and other responsibilities. Aimed primarily at those with little or no formal educational qualifications, courses in subjects ranging from childcare to English, office skills to culinary studies, take place at different times of day and week to accommodate learners' schedules. Offered at Second Level Schools, Further Education and Training Centres, and Community Education Centres, the courses are usually level 3 and 4 on the National Qualification Framework (NFQ) and allows people to study part-time (up to 400 hours per year).

\section{KLEAR}

Supported by the City of Dublin Education and Training Board, and co-funded by the European Social Fund and Ireland's Department of Employment Affairs and Social Protection, KLEAR is a community-based adult education centre that offers a range of part-time classes in general education, literacy and languages. For unemployed adults seeking to re-enter the workforce, KLEAR provides community employment opportunities with local employers to enhance technical and personal skills development. For individuals with solid education and skills already, KLEAR offers an adult guidance service which provides information on further education, certification and training.

Source: Citizens information, Back to Education Initiative,

https://www.citizensinformation.ie/en/education/returning_to_education/back_to_education_initiative.html and https://www.klear.ie/about/.

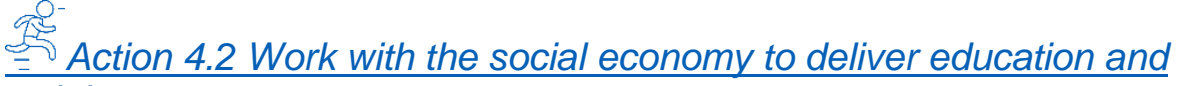 training}

Across countries, social economy actors play a key role in supporting different groups in their efforts to gain or maintain labour market attachment. The social economy often has strong local roots and can drive innovation in the delivery of employability programmes and social support measures for more groups at risk of getting left behind. To strengthen the provision of integrated adult learning models for those furthest away from the labour market, local governments can seek to develop strategic partnerships with social economy actors present in the local economy. Green Connect is an example of an adult learning programme provided by a social economy actor in Wollongong, Australia (Box 15). 


\section{Box 15. A green social enterprise creating more jobs in Wollongong (Australia)}

Green Connect, a social enterprise in Wollongong, Australia, works to create more jobs, less waste and fair food. The main objectives of the social enterprise, which was launched in 2011, is to tackle unemployment, waste and an unsustainable food system. To achieve their environmental aims, Green Connect sells fair food to local residents and businesses, provides zero waste services to help reduce landfill waste, and sells or recycles donated second-hand goods through an opportunity shop. To address unemployment, the enterprise creates jobs for people who experience barriers to employment, particularly, young people and former refugees. Green Connect employs young people and former refugees to grow fair food on an urban permaculture farm and offers labour hire and recruitment services, where the enterprise connects their staff to businesses and industries. Most of the employees have no prior work experience and, thus, the organisation gives them the first access to the labour market. In addition, Green Connect provides support for their staff to transition from the organisation to other meaningful, long-term jobs. From 2017 to 2019, Green Connect employed 166 former refugees and young people, created 42000 hours of paid work for the target groups and transitioned more than 30 staff members into mainstream employment.

Source: (Green Connect, $2021_{[35]}$ )For more information go to Future-proofing Adult Skills Systems in Cities: Case Studies $\underline{O E C D .}$ 



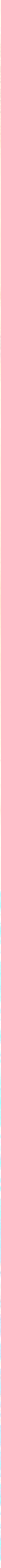




\section{Getting employers on board and meeting local skills demand}

\section{In brief}

The demand for skills is changing rapidly in the context of changing labour markets. While some skills are becoming obsolete and some occupations are disappearing or changing, the demand for new types of skills in existing as well as emerging sectors is increasing. Combined with demographic changes and the need for workers to stay longer in the labour market, the role of responsive adult learning systems that can enable individuals to continuously re- and upskill in order to stay employed or find new jobs is only getting bigger and bigger.

Cities and regions face different skills challenges, reflecting the fact that there are multiple overlapping local labour markets rather than one national or global labour market. Therefore, local governments face a significant task in making sure that skills systems are geared towards the specific changes that their local area is facing. The task is not only to produce more or better-quality skills but also to produce the right skills to meet the specific need of local employers and local economies now and in the future. Through their closeness to workers, providers and employers, local governments are already working to make their adult learning systems more resilient and responsive to changing local needs.

\section{Table 2. Key policy areas and actions}

Getting employers on board and meeting local skills demand

Key policy area

1. Get the data right - assess local skills supply and demand

2. Implement measures to match supply with demand

3. More actively engage employers in skills provision
Actions

1.1 Make strategic use of skills assessment and anticipation exercises 1.2 Consider targeted local skills assessment and anticipation exercises

2.1 Adjust the provision and content of learning offers to growing sectors 2.2 Provide incentives and information to guide learning choices

3.1 Provide targeted support to local SMEs and entrepreneurs 3.2 Build strong local leadership and partnerships with employer 


\section{Why is it important?}

Global megatrends, including digitalisation, the green transition and the ageing of societies, are changing the demand for skills. These transformations will destroy, transform and create jobs, but often not in the same place or time, or requiring the same type of skills. With COVID-19, many of the ongoing changes are likely to accelerate. Digitalisation and automation are likely to pick up in speed due to the introduction of social distance requirements among other things, and the green transition is likely to receive momentum as part of stimulus packages.

The effects of global changes vary significantly across local economies. Often labour market changes are concentrated in specific regions or sectors, and often there is a significant time gap between the destruction and creation of jobs - resulting in geographically concentrated skills mismatches. Compared to other subnational areas, large cities tend to host substantial shares of high-skilled workers that work under standard contracts and with good teleworking options, which makes cities more resilient to ongoing changes. Yet, cities also host many low-skilled workers with little opportunity for teleworking (OECD, 2020[36]).

Already today, many local areas show signs of misalignment between the provision of skills and the actual skills needed in the labour market. One such sign is the self-reported training needs among workers. Across OECD countries, $35 \%$ of workers report that they do not have all the skills needed to do their current tasks and need more training (OECD, 2019 $\left.{ }_{[4]}\right)$. Data from selected OECD metropolitan areas confirms this picture (Figure 4).

Figure 4. Skills mismatch are widespread in many OECD metropolitan areas

Percentage of workers across metropolitans areas occupying jobs that do not match their educational attainment
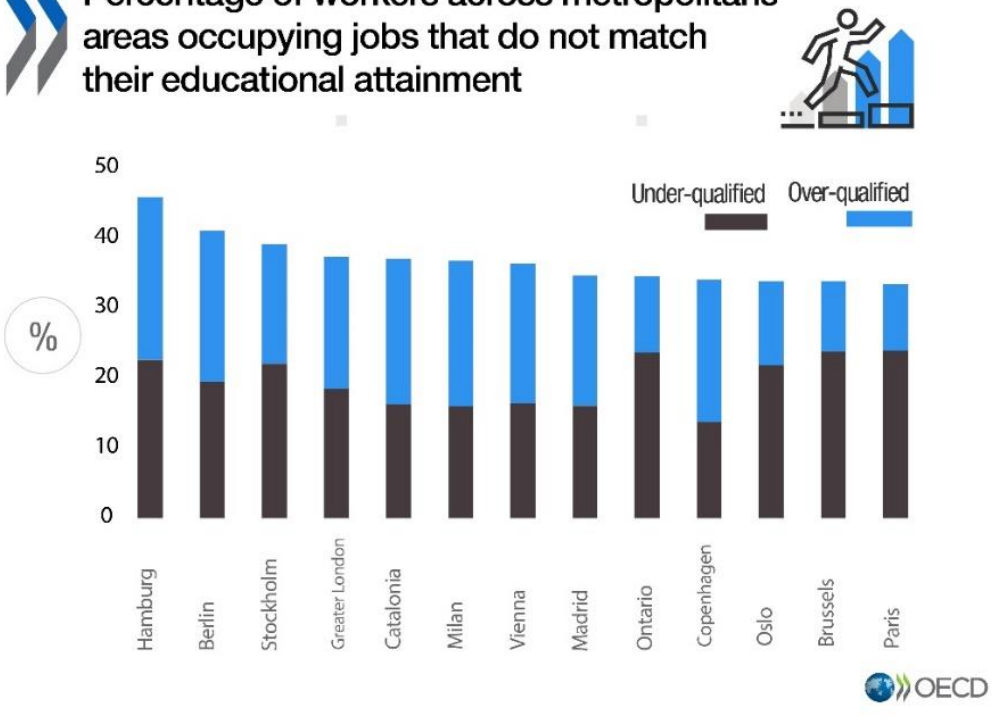

Note: ISCED groups 0-2, 3, 4, 5-8. For Canada, ISCED groups 0-2, 3, 4, 5-6. ISCED groups 302, 303 and 304 are considered to be 3 according to the newest 2011 isced classification.

Source: OECD calculations on European labour force survey 2018 and Calculations based on Stats Canada Census 2016. 
Another sign of skills misalignment is the hiring difficulties reported by employers. Across OECD countries, $42 \%$ of employers state that they have difficulties filling jobs and $35 \%$ of workers report that they do not have all the skills needed to do their current tasks. In addition, on average $40 \%$ of companies in countries for which data is available report that the lack of availability of staff with the right skills is a major obstacle to long-term investment decisions (OECD, 2019 $9_{[4]}$ ).

Re- and upskilling through adult learning is a key lever to address local skills imbalances. Changing labour markets and skills requirements means that local employment and skills systems must be flexible and responsive to individual and employer demand. Without demand-led adult learning systems that effectively coordinate the current and anticipated needs of employers with the local supply of skills, cities and local governments will not be able to respond quickly to changing skills needs, and skills shortages and mismatches are likely to arise.

Some degree of local skills mismatch is hard to avoid in the short term. Yet, in the longer term, it risks resulting in substantial costs for individuals (negative impact on job satisfaction and wages), employers (reduces productivity and increases onthe-job search and turnover), and society (increases unemployment and reduces GDP growth) (OECD, 2012[37]; OECD, 2014[6]; Adalet McGowan and Andrews, $2015_{[38]}$; Montt, $\left.2015_{[39]}\right)$. Results from the OECD survey on adult learning in cities and regions show that this challenge is well recognised. After "tackling high unemployment levels", "meeting the changing skills needs of employers" is the main labour market challenge facing the labour markets of participating cities and regions (Figure 5).

Figure 5. The most pressing challenge facing cities' and regions' labour markets

\section{What is the most pressing challenge facing your city's or region's labour market?}
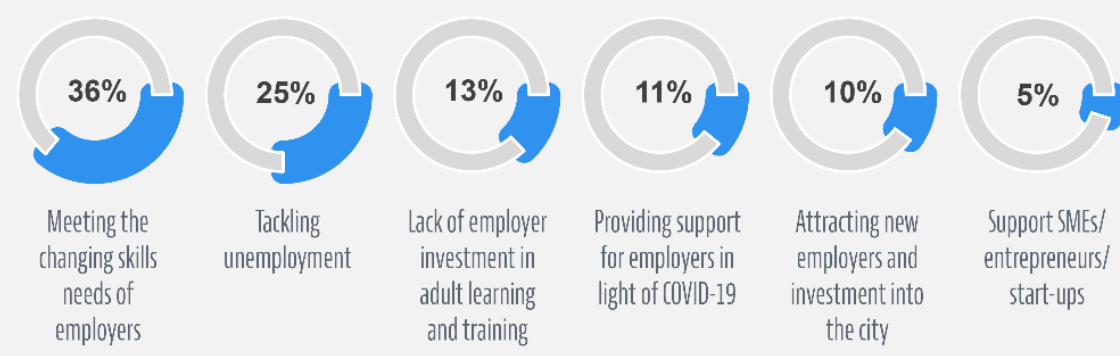

Note: Participating cities and regions have answered the question "What is the most pressing challenge facing your city's labour market

Source: OECD/Eurocities survey on adult learning systems in cities and regions, 2021 
The Workforce Planning Boards in Ontario, Canada, the Excelsior information system in Italy, and the Network of Regional Skills Fora in Ireland are all good examples of how more centralised SAA exercises are set up to provide local governments with data to understand local skills supply and demand (Box 17).

\section{Box 17. Centralised SAA exercises to support local government needs}

\section{Workforce Planning Boards in Ontario (Canada)}

Workforce Planning Ontario, a network of workforce planning boards, has the mandate to connect labour market stakeholders within the Canadian province of Ontario. Through a network of 26 planning boards that covers four regions across the province, Workforce Planning Ontario seeks to conduct localised research of ongoing labour market changes and identify skills shortages and future training requirements throughout Ontario. Each planning board gathers intelligence about the supply of labour and the demand of skills within their local labour market by working with employers to identify and meet their current and emerging skills needs. The governing body of each of the boards is as unique as the community it serves, and it generally includes members from business, labour and education as well as community representatives from various groups (e.g. women, aboriginal people, and persons with disabilities). The boards undertake a range of activities, including profiling trends, opportunities and priorities of local labour markets, identifying skills shortages and future training requirements, sharing research with the community, and undertaking projects that address labour force issues. Some boards also conduct employer surveys, which query employers regarding their hiring needs.

\section{Excelsior - The Italian Information System for Employment and Training (Italy)}

Excelsior is a skills assessment system created in co-operation between the Italian Ministry of Labour and UnionCamere (Italian Union of Chambers of Commerce, Industry, Handicrafts and Agriculture) in 1997 with the support of the European Union. Through a co-operation with the network of regional and local Chambers of Commerce in Italy, the system provides data at regional and local levels on labour market trends, and the professional and training needs of companies across the country. The system also provides statistical data on the hiring planned by companies at national, regional and provincial levels, and tailored tables and graphs on professions, sectors and education levels sought by companies.

\section{The Network of Regional Skills Fora in Ireland}

In 2016, the Department of Education in Ireland published the National Skills Strategy 20162025. A key element of the National Skills Strategy was the establishment of a National Skills Council, which oversees research, advice on prioritisation and delivery of identified skills needs, and has a role in promoting and reporting on the delivery of responses by education and training providers at the national level. In addition to the National Skills Council, the National Skills Strategy also includes the creation of a Network of Regional Skills Fora. While the National Skills Council provides a mechanism to mediate demands across the full range of needs identified nationally, the Network of Regional Skills Fora provides an opportunity for employers and the education and training system to work together at the regional level to meet the emerging skills needs of their regions. Among other things, the Fora provide a single contact point in each region to help employers connect with education and training providers, more robust labour market information and analysis of employer needs at the regional level to inform programme development.

Source: (Burning Glass, 2019[43]; Urban Innovation Action, 2021 [44]; Workforce Planning Board Ontario, 2021 [45]; Department of Further and Higher Education, 2022[46])For more information go to Future-proofing Adult Skills Systems in Cities: Case Studies - OECD. 


\section{Action 1.2. Consider targeted local skills assessment and} anticipation exercises

In some cases, it may be relevant for local governments to undertake their own local SAA exercises independent from more centralised exercises. This may be in situations where there is a need for very specific knowledge on the development of certain sectors or skills sets in a local area. In these cases, local governments must ensure that the SAA exercises are manageable and can be undertaken within the resources and capacities available.

One way to make these exercises more manageable is to undertake them in collaboration with other local stakeholders who can provide information or tools to support the analyses. Such stakeholders may include local businesses, social partners, training providers, local branches of public employment services, regional- or sector-specific institutions and civil society actors. Beyond being a good way to pool local resources, the engagement of stakeholders can also ensure that 1) exercises are designed to meet the needs of its users; 2 ) a consensus is reached about local skills need; and 3) the policy responses adopted across local actors are coherent and complementary (OECD, 2016[42]).

Another important way to make local SAA exercises more manageable for local governments is to target these exercises. This may include the adjustment of scope and time span (e.g. to focus on the short-term (6 months to 2 years) rather than medium- or long-term scenarios) and to limit the exercise to a selected number of industries or sectors relevant in the local labour market. The cities of Southampton, the United Kingdom, and Aveiro, Portugal, have developed local SAA exercises that are targeted specifically to certain sectors and needs of the cities, in co-operation with other local stakeholders (Box 18). 


\section{Box 18. Local initiatives}

\section{Southampton's Local Approach to the Future of Work (the United Kingdom)}

From September 2018 to March 2019, Southampton carried out an extensive inquiry on the future of work in the city to develop a strategy shaping the city's future growth. The inquiry, led by a panel comprised of elected officials, was held to consider how the city could maximise the opportunities created by Artificial Intelligence (Al), automation and technological changes. At the same time, it aimed to identify and mitigate potential disruption to the local economy, particularly for workers in sectors that are most likely to see the greatest increase in the level of these technologies. As part of the inquiry, the city council gathered advice and insights from experts and local practitioners both within the city and in other cities. The resulting action plan identified main actions the city could undertake, including, for example, the development of a citywide skills strategy and the update of education curricula to enrich the offer of digital skills, as well as an analysis of the current skills offer by education providers in the city. As part of the strategy, the city could also map existing platforms facilitating lifelong learning across Southampton to find ways to improve access, improve rates of progression, and increase job outcomes.

\section{Portuguese city of Aveiro 'steams' towards a digital economy (Portugal)}

The City of Aveiro is running the STEAM City project, to help establish a digital, knowledgebased economy in Aveiro by strengthening the provision of science, technology, engineering, arts and mathematics (STEAM) skills. Central to the project is the Aveiro Labour Observatory, which provides assessments of the skills needed for the local economy. The project has a dual approach to making Aveiro a digital economy: the first is ensuring that the education system adequately meets labour market needs; and the second is experimenting with $5 \mathrm{G}$ and Internet of Things (IoT) technologies to encourage the development of new products and services in the city. Under the first part of the project's approach, the Labour Observatory conducts multiple activities aimed at diagnosing and assessing the skills needs in the local economy in close dialogue with local companies and other stakeholders working in the area of STEAM skills. The activities of the Observatory include conducting workshops, interviews and questionnaires addressing local companies and other entities as well as other forms of research and data collection. Based on this work, the Observatory provides information about the demands for skills and competences, which in turn influence the design and implementation of short-term courses to meet local labour market needs. The activities of the Observatory are developed by a multidisciplinary team that brings together researchers across different scientific domains.

Source: (DNAsix, 2021 [47])For more information go to Future-proofing Adult Skills Systems in Cities: Case Studies - OECD. 


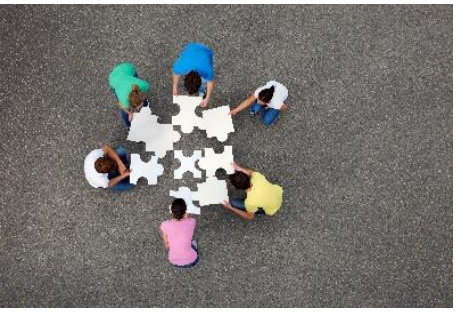

\section{Key policy area 2: Implement measures to match supply with demand}

Once SAA exercises have been conducted to understand skills supply and demand locally, adult learning policies should be adjusted accordingly. Within recent years, many countries have gradually shifted towards more demand-side management of adult learning, leaving more of the choice and financing of training to individuals and employers, and creating more competition between providers. This may improve the efficiency and quality of the system by letting the demand guide supply. Yet, this strategy can only work if the supply-side is responsive to the demand of individuals and employers, and if measures are taken to avoid market failures (OECD, 2017[28]).

A significant risk in "adult learning markets" is information failure. Individuals may not have reliable information on the types of courses that lead to the best labour market outcomes and employers may not always be aware of their training needs and the training options that exist. In the context of a more market-driven supply of adult education and training, local policy makers must find ways to steer, nudge and even more directly control providers so to adjust the provision and content of programmes to local labour market demands (OECD, 2019[4]]).

Action 2.1 Adjust the provision and content of learning offers to growing sectors

Local governments may regulate the provision of courses, course content and curricula to meet local skills demand and steer skills production towards those sectors that are expected to grow in the future. The rising importance of green and digital technologies, as well as the social, health and elderly care sectors, may prove valuable sources of job creation, and education and training services will need to prepare future workers for these sectors. In addition, local policy makers can also seek to target the provision of adult learning towards those workers whose core skills have become obsolete.

Technological advances and digital innovations, such as Al, automation and robotics, have a profound impact on our labour markets and the demand for skills. Increasingly, digital skills (i.e. the range of abilities to use digital devices, communications applications, and networks to access and manage information) are considered just as important as reading, writing or numerical skills for employability and participation in society more broadly. Digital skills are needed not only in sectors and industries directly related to the digital economy (e.g. computer engineering or coding), but also in more "traditional" industries such as manufacturing, the food industry and the service sector (OECD, 2021 [48]).

Within their local competences, many local governments are adjusting the provision and content of adult learning programmes to increase the volume and quality of digital training within their local economies. Inspiring examples hereof are the IT Academy in Barcelona, Spain and the Digital Talent Programme in London, the United Kingdom, which are local programmes that seek to address the digital skills gap and promote inclusion in the digital sectors (Box 19). 


\section{Box 19. Local programmes to up- and reskill for the digital future}

\section{Barcelona's IT Academy provides IT re- and upskilling for professionals (Spain)}

Through its Local Development Agency, Barcelona Activa set up the Barcelona IT Academy in 2017 to develop and upgrade the digital skills of professionals in the city. The main objective of the academy is to promote job opportunities, reinforce competitiveness, promote social inclusion, and reduce the gender gap in the digital sector. The IT Academy collaborates with IT companies to define training modules and provide job opportunities, and with academic institutions to promote Barcelona's work in this sector. The IT Academy provides a two-fold training and learning offer. First, the academy offers re- and upskilling courses and training for professionals outside the IT sector to address the digital skills gap and to provide people with job opportunities in the technology sector. Secondly, the academy offers lifelong learning activities to upskill professionals who already have IT knowledge to ensure that they maintain their employability. The IT Academy's training for professionals new to the IT sector applies an innovative learning method based on mentoring where an expert accompanies the student in his/her learning process. This learning process involves access to open educational resources, participation in simulation projects, and peer-to-peer learning among students.

\section{Digital Talent Programme in London (the United Kingdom)}

London is experiencing a growing digital skills shortage due to a boom in labour demand in digital, creative and technology sectors. The Digital Talent Programme aims to increase the volume and quality of training in digital technology and thus increase employment opportunities for young people, especially women, disadvantaged groups and individuals from black and ethnic minority backgrounds. The programme consists of a range of projects designed to address several inequalities in the sector, including underrepresentation of female workers and workers with black and ethnic minority backgrounds. The programme provides 1) opportunities for individuals 18-24 years old to gain digital skills, career advice and support to set up their own digital business in the technology sector; 2) support for employers and educators to improve digital career guidance for young people and facilitate partnerships with higher education institutions and SMEs; and 3) research, resources and case studies to give insight into the tech and digital sectors.

Source: OECD/Eurocities survey on adult learning systems in cities and regions. For more information go to Future-proofing Adult Skills Systems in Cities: Case Studies - OECD.

In light of changing demographics and in the context of the COVID-19 pandemic, many OECD countries are also experiencing an increasing demand for workers in the health and long-term care sectors. Across countries, these sectors suffer increasingly from a shortage of workers, which among other things is caused by insufficient training and skills provision resulting in skills mismatches (OECD, 2020[49]). To overcome these challenges, local governments are setting up re- and upskilling programmes directly targeted the care sectors. One interesting example hereof is in Munich, Germany, where the city has developed a programme to support skills development in the care sector (Box 20). 


\title{
Box 20. Improving the attractiveness of jobs and training in the care sector in Munich (Germany)
}

To overcome key labour market challenges, the city of Munich has developed a comprehensive approach to skills development in the care sector. The programme includes a number of actions and projects, including a three-year pilot project with the aim of carrying out public relations work in schools and youth welfare and integration facilities in order to make people who are looking for apprenticeships aware of relevant offers in the sector. The programme also includes a pilot project funded by the European Solidarity Corps within the Erasmus+ Programme targeting individuals who have qualified as a nurse and would like to gain their first experience as interns in Munich care facilities. In addition, the programme includes a project offering counselling and assistance for people with foreign qualifications in the care sector, and a project offering a preparatory year to start a one-year vocational training course as a state-approved nursing assistant or a three-year training course as a nursing specialist at the Munich City Clinic .

Source: OECD/Eurocities survey on adult learning systems in cities and regions. For more information go to Future-proofing Adult Skills Systems in Cities: Case Studies - OECD.

\begin{abstract}
Lastly, the transition towards a more green economy means that "green skills" to match "green jobs", e.g. in the renewable energy sector and the transport sector, are increasing in demand. As governments step up their commitments and actions to achieve national and global climate and sustainability goals, green jobs are growing not only in the traditional "green industries" but also in industries such as finance, fashion and health care. An example of how local governments are working to adapt their local labour force to the green economy is found in Madrid, Spain, where the city has launched a comprehensive training and employment project focused on sectors related to the "circular economy" (Box 21).
\end{abstract}

\section{Box 21. The Circular Economy: Jobs for the Future project in Madrid (Spain)}

In co-operation with the Fundación Adsis and the JPMorgan Chase Foundation, the city of Madrid has developed a comprehensive training and employment project with the purpose to improve the employability opportunities of young people (18-30 years old) in the community of Madrid. The project includes 12 training itineraries that all relate to the "Circular Economy" and seeks to enable young people to have a quality job that contributes to the ecological transition. The 12 training itineraries cover areas such as solar energy, transport and delivery, urban landscape design and dispatch and packaging of fresh products. Each itinerary is composed of 4 modules - professional competences and social skills, technical training, workshops for the labour qualification and incorporation of practical training in companies in the sector.

Source: (Fundación Adsis, n.d.[50]) 
Action 2.2 Provide information and incentives to guide learning choices

Another way to steer the choice of individuals and employers towards indemand skills is through information. Information to individuals and employers on local training and employment opportunities have proven effective as a way to steer individual choices on adult learning (see also Chapter 1). The provision of information and career guidance tend to fall within the competences of local governments and thus these are measures used in numerous cities and regions.

An example hereof is the Mayor's Construction Academy in London, the United Kingdom, where they have developed a quality mark to guide individual choices on which companies and organisations provide high-quality training and education (Box 22). This has proven an effective but also ambitious way to guide individual choices. For local governments with more limited resources, alternative ways of providing information may be used, e.g. through local information sites, career guidance officers or even local newspapers.

In addition to information, local governments may use financial incentives to guide the choices of individuals and employers (OECD, 2017 $[28]$ ). Although there has been a devolution of adult learning funds to lower levels of government in some countries such as the UK in recent years, opportunities for cities and regions to strategically direct funding to address local needs remains limited. Nevertheless, some local governments are finding ways to prioritise additional funding to this area (see Action 3.1 and Chapter 3). In addition, some local governments make the most out of financial incentives regulated at the national level. Another example from London, the United Kingdom - The London Progression Collaboration - shows how local governments can use flexibility within existing financial measures to support training provisions within local SMEs (Box 22). 


\section{Box 22. Incentives and information to guide choices}

\section{The Mayor's Construction Academy in London (the United Kingdom)}

To address the growing construction skills shortage in London, England, and provide the construction sector with the site-ready workforce it requires, the Mayor of London set up and launched the Mayor's Construction Academy (MCA) in 2018. The MCA seeks to connect Londoners with training in the skills they need to access to benefit fully from the opportunities in London's construction sector. The Academy includes among other things a quality mark, which identifies and recognises organisations that provide high-quality construction skills training in London. This quality is measured in terms of the curriculum, routes to employment and strong links with employers. It also includes hubs to help Londoners, employers, training providers and the organisations supporting them to connect more frequently, more rapidly, and with better outcomes. In total, seven hubs have been established across London. Lastly, the programme includes investment in equipment and facilities to support the delivery of highquality construction training in London.

\section{The London Progression Collaboration (the United Kingdom)}

Since the introduction of a national apprenticeship levy in 2017, the number of apprenticeships has fallen across the UK, including in London. One measure introduced by the government to reverse this trend is greater flexibility for larger firms with unspent levy funds to transfer these funds to SMEs in order to provide the impetus needed to help these smaller firms create apprenticeship opportunities. The Greater London Authority is taking advantage of this flexibility at the local level through the London Progression Collaboration, which is a partnership between the Greater London Authority and Institute for Public Policy Research (a UK-based think tank) to support employers in creating good quality apprenticeships. Through the partnership, the city is providing levy transfer brokerage and support services for Londonbased employers, and thus helping larger firms in London identify the amount and manner in which they would like to transfer unspent levy funds to smaller firms in London (up to $25 \%$ of their total levy) to meet their strategic objectives. Until now, the project has resulted in the creation of more than 500 new apprenticeship opportunities in priority sectors (digital, construction, hospitality, retail, and health and social care).

Source: (OECD, 2021[32]). OECD/Eurocities survey on adult learning in cities and regions. For more information go to Futureproofing Adult Skills Systems in Cities: Case Studies - OECD.

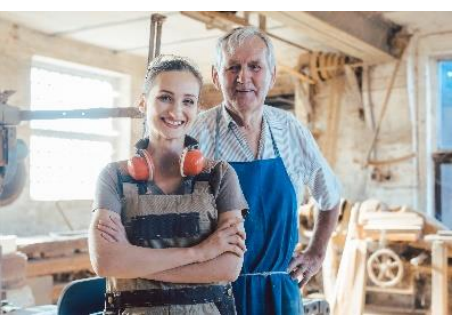

\section{Key policy area 3: More actively engage employers in skills} provision

Employers play a key role in the provision of adult training not least because a large share of training and education takes place in the workplace. While data from European countries shows that firms generally engage in training provision (Box 23), local governments still experience barriers to employer engagement in training especially among SMEs, entrepreneurs and start-ups.

There are many ways that local governments can engage employers in adult learning policies. These include financial incentives that encourage employers to train by lowering the cost of training or information to firms about the benefits of training and the availability of training opportunities. 


\section{Box 23. Employer engagement in training - Evidence from Europe}

Data from the European Continual Vocational Training Survey (CVTS) shows that many firms in EU countries provide Continuing Vocational Training (CVT), and that this share has increased gradually over the past decade. For firms with more than 250 employees, there has been an increase in the percentage of firms providing CVT from around $85 \%$ in 2005 to around $90 \%$ in 2015. Despite an even bigger increase in the provision of CVT for firms with 10-49 employees (from around $45 \%$ to around $55 \%$ of firms providing training), smaller firms still tend to train much less than larger firms. Among those employers who do not train, many admit that they prefer to recruit new staff rather than to provide training for their existing workforce. Other key reasons are high training costs and a lack of time for staff. Evidence also shows that employers are particularly unlikely to invest in the training of low-skilled staff, not least because low-skilled workers are increasingly employed on a temporary basis, which reduces the incentives for employers to invest in re- and upskilling opportunities.

Source: (OECD, 2019[14]).

\section{Action 3.1 Provide targeted support to local SMEs and}

\section{entrepreneurs}

SMEs, entrepreneurs and starts-up all face special challenges when it comes to the provision of training to their employees. Smaller firms still tend to train much less than larger firms, among other reasons due to a lack of financial resources, HR resources or information on available training and co-financing programmes. As these firms make up a significant part of many economies, this presents a significant challenge for local governments.

To overcome this challenge, local governments may seek to provide targeted support to smaller local businesses. This may include information, financial support or assistance in managing administrative and HR functions in relation to internships and apprenticeships. In Glasgow, Scotland, the city has put in place the Glasgow Guarantee, which includes targeted support for local SMEs in recruiting and training their employers. In Vantaa, Finland, the Urban Growth Vantaa Project support both local SMEs and their employees in re- and upskilling (Box 24). 


\section{Box 24. City-level support for training and education in SMEs}

\section{The Glasgow guarantee - supporting jobseekers and SMEs (Scotland)}

In 2015, the City of Glasgow in Scotland, established an employment programme known as the Glasgow Guarantee. The objective of the programme is to support the city's residents in training and employment opportunities and help local businesses to grow and prosper. The programme targets 1) Glasgow residents who are unemployed or about to leave school or college, and 2) Glasgow-based businesses that employ less than 250 staff. For residents looking for jobs, the programme provides access to a large number of vacancies and apprenticeships; for those still in school or college, it provides full support from a local PES provider for those who have been out of work for a longer period, access to an individual online account to view and apply for vacancies, and a guarantee of being paid the Glasgow Living wage whilst in a job or apprenticeship. For local businesses, the programme provides, among other things, support in recruiting the needed talent, additional funds for training, and help in managing the apprenticeship-related administrative and human resource functions of employers. The City Council's service of managing the administrative and HR functions of employers includes advertising vacancies, handling recruitment (young residents interested in apprenticeships with companies apply to the City Council rather than to employers) and sometimes managing the shortlisting of applicants (the Council may manage the recruitment process, giving feedback to both successful and unsuccessful applicants).

Source: (Glasgow Guarantee, 2021 [51]). For more information go to Future-proofing Adult Skills Systems in Cities: Case Studies - OECD.

\section{The Urban Growth Vantaa Project (Finland)}

The Urban Growth Vantaa project brings together the relevant city departments, education providers, research institutes and businesses in Vantaa to develop a local jobs and skills ecosystem with the aim of supporting both local SMEs and their employees in employment, re- and upskilling and digitalisation. The primary target group of the initiatives are low-educated adults employed by SMEs who do not traditionally fall into the category of continuous learners. This specific group is often at risk of job loss due to the automation of production processes. A second target group is executives of SMEs who aim to grow their company responsibly. Employees in SMEs are typically supported through a co-created apprenticeship services programme. These apprenticeships are targeted at individuals as an opportunity to earn a vocational degree. Urban Growth Vantaa's solution is to contact companies to introduce training ideas and their benefits to SME decision-makers and employees simultaneously. In a first step, SMEs with 10-200 employees are contacted by the project co-ordinators. SMEs then undergo a needs assessment to identify skills needs through surveys. A discussion with the individual employees then follows and an appropriate apprenticeship is identified for them. The apprenticeships are free of charge for employees, and the SMEs continue to pay their full salaries. If the reduction in working hours at full salary cannot be borne by SMEs, financial support schemes exist. Alternatively, employees of SMEs can be trained through a so-called growth-coaching programme. The programme follows a similar structure but takes a forwardlooking approach. Business development needs are identified in consultation with SME executives and employees then undergo the appropriate training to meet these needs.

Source: (Urban Innovative Actions, $2021_{[52]}$ )For more information go to Future-proofing Adult Skills Systems in Cities: Case Studies - OECD. 


\section{Action 3.2 Build strong leadership and employer partnerships}

Another way to ensure employer engagement is through the development of local employer partnerships. Employer partnerships may be used to develop more formalised agreements that define common values, objectives and measures (see Chapter 3). An example is the Humber Skills Pledge in Humber (a large tidal estuary on the east coast of Northern England), the United Kingdom, which was launched in 2013 to promote investment in skills and training among employers (Box 25).

\section{Box 25. Engaging employers in skills provision through partnerships}

\section{The Humber Skills Pledge (the United Kingdom)}

To promote the value of investing in skills and training and demonstrate the significant benefits that such investment can bring to businesses, employees, the local community and the economy, the Humber Local Enterprise Partnership (LEP) launched a Skills Pledge in 2013. The main objective of the Skills Pledge is to encourage and help businesses access vital skills and training organisations to help them succeed and grow. More specifically, the ongoing partnership campaign seeks to encourage joint working between education and training providers, employers, local councils and organisations, including local public employment service offices. Among other things, the campaign provides one point of call for businesses in the Humber area to access training and skills information. As part of the pledge, businesses sign up to one or more of the following areas: 1) Invest in increasing the skills of their workforce; 2) Mentor a budding entrepreneur; 3) Offer a work placement to a young person or adult; 4) Employ a graduate; 5) Offer an apprenticeship or traineeship; and 6) Support the development of employability skills. After signing up, the employer is contacted by the LEP to get advice, e.g. on skills investments, on getting in touch with organisations with young people waiting for a mentor, or offering a work placement to a young person or adult.

Source: (Humber Local Enterprise Partnership, $\left.2021_{[53]}\right)$ For more information go to Future-proofing Adult Skills Systems in Cities: Case Studies - OECD.

Employer engagement in training and education can also be strengthened through the involvement of Chambers of Commerce and Industry at the local and regional level. Chambers can be involved in many parts of the adult learning system, including career guidance provision, skills forecasting and assessment (see also Box 17), development and provision of training courses and involvement in advisory bodies or local partnerships. Across Europe, $80 \%$ of Chambers of Commerce and Industry are involved in education and training and $48 \%$ deliver initial or continuous vocational and education and training (Eurochambres, 2019[54]). Often this involvement takes place at local or regional level. As an example, in Germany, the German Chamber of Commerce (IHK - Industrie- und Handelskammer) runs regional training centres across the country, which among other things provides training opportunities and training counselling to citizens in the regional areas (OECD, 2022[55]). 


\section{Creating strong local skills ecosystems}

\section{In brief}

The organisation of adult learning systems differs significantly across OECD countries. Despite great divergences between OECD countries, a common feature of adult learning systems is their complexity and fragmentation with regard to the actors involved and their different responsibilities. This may be a challenge for policy makers and practitioners at the local level who need to co-ordinate with different levels of government, as well as with providers, learners and businesses in their own communities.

Yet, at a time when public budgets are becoming increasingly tight and the demand for adult learning is increasing, fragmentation among actors, goals and policies is no longer an option. Moreover, given the considerable diversity in local labour markets, the organisation and governance of adult learning systems must allow for the necessary flexibility for local governments to establish demandled skills systems. Across cities and regions, local governments are bringing together all relevant actors to create strong local skills ecosystems. Such systems are based on co-ordination across different levels of government, collaboration of all key local actors, strong governance mechanisms and sufficient financial means.

\section{Table 3. Key policy areas and actions}

\section{Creating strong local skills ecosystems}

Key policy areas

1. Improve co-ordination with higher levels of government

2. Strengthen co-ordination with local actors

3. Develop coherent financing models at all levels of government
Actions

1.1 Develop partnerships across different levels of government

1.2 Establish formal boards bringing together different levels of government 1.3 Engage in dialogue with national government on new competences

2.1 Engage private actors in local skills partnerships 2.2 Work with neighbouring municipalities

3.1 Negotiate flexible financing arrangements with higher levels of government

3.2 Develop local skills financing pacts between local stakeholders 


\section{Why is it important?}

There is no simple answer to "who does what" in adult learning systems. Decision-making and funding responsibilities are split not only across levels of government, but also across different departments, ministries and agencies at any given level. Delivery involves a range of educational institutions and training providers, as well as employers, operating mainly at the regional and local level (OECD, 2019[4] ; OECD, 2020[54]).

Adult learning systems also encompass a range of policies and programmes with different objectives and different target groups - including basic skills courses for the low-skilled, professional training for workers, activation and training for the unemployed, re- and upskilling of workers, or language classes for migrants. In addition, adult learning policies often overlap with other policy sectors including social, employment policies, economic development as well as other skills policies including higher education (HE) and vocational education and training (VET).

At the local and regional level, the fragmentation of responsibilities and the broad range of stakeholders involved presents both a challenge and an opportunity. On the one hand, given their proximity to providers, learners and employers, local governments are often the first to feel the consequences of incoherent systems of which they at best have only partial control. On the other hand, despite their limited competences, local governments are often well placed to act as a centre and initiator of local skills coalitions or partnerships of public, private and non-profit organisations to ensure that skills provision links to local economic priorities and needs.

One of the most decisive issues for cities is what level of government holds decision-making power for adult learning systems, i.e. the level of centralisation or decentralisation. Some countries (e.g. Portugal) have a more centralised system, where the national government is responsible for most of the policy design, implementation and financing. Other countries (e.g. Italy and Korea) have more decentralised systems where responsibilities are shared between the national and regional or local level. In countries with federal systems (e.g. Canada and the United States), sub-national levels of government tend to have most of the responsibility within nationally defined objectives (OECD, 2020[54]).

Most adult learning systems in OECD countries allow for at least some local decision-making and tailoring of policies to local needs. Results from the survey on adult learning in cities and regions show that many different models exist - from some cities and regions having very limited responsibilities and only undertaking ad hoc work on adult learning to others having the main role in design, implementation and delivery of policies. Interestingly, a majority of participating cities and regions indicate that their responsibilities are limited but that actual work goes beyond their legal competences (Figure 6). For those cities and regions that have responsibilities, these often relate to the provision of communication and information, provision of career guidance, choice and design of adult learning programmes and financing. The survey also shows that a majority of cities and regions (87\%) allocate financing within their own local budgets to adult learning. In some cases, this is up to $10 \%$ of their overall budget (Figure 7). 
Figure 6. Cities and regions play many different roles in designing and implementing adult learning systems

\section{What role does your city or region play in the governance of your} country's adult learning system?

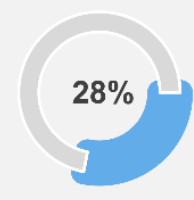

Designed nationally but responsibility for implementation

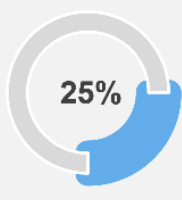

Main role in

designing,

implementation

and delivery

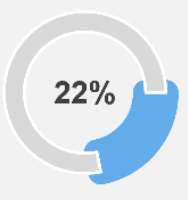

Responsibilities

are limited but

work goes beyond

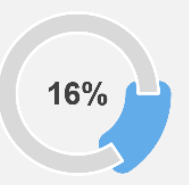

Designed

nationally but

local government

can select

programmes
$9 \%$

Responsibilities

are limitied and

only ad hoc work

Note: Participating cities and regions have answered the question "What role does your city play in the governance of your country's adult learning system?"

Source: OECD/Eurocities survey on adult learning systems in cities and regions, 2021.

Figure 7. Most cities and regions allocate financing within their own budgets to adult learning

\section{Does your city or region allocate financing within its own budget to adult learning? If yes, please indicate percentage}
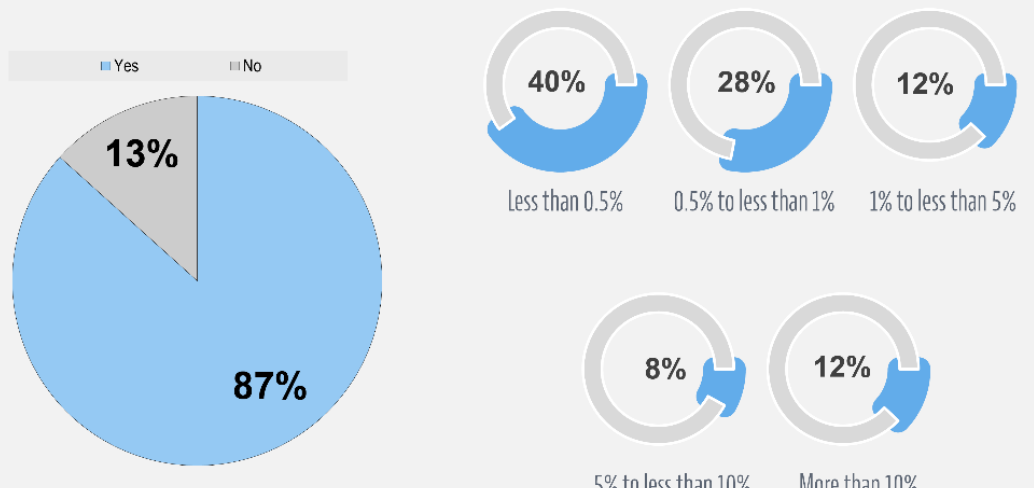

$5 \%$ to less than $10 \% \quad$ More than $10 \%$

Note: Participating cities and regions have answered the question "Does your city allocate financing within its own budget to adult learning? If yes, please indicate approximately what percentage of your overall budget is allocated to adult learning".

Source: OECD/Eurocities survey on adult learning systems in cities and regions, 2021. 


\section{Key policy areas and actions}

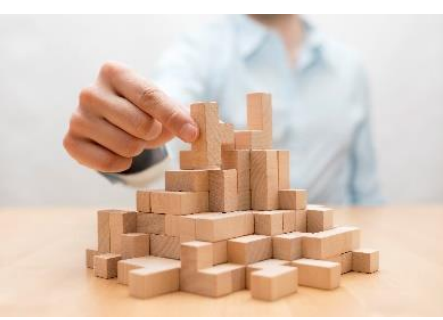

\section{Key policy area 1: Improve co-ordination with higher levels of government}

In any system where responsibilities for adult learning policies are spread across levels of government, vertical co-ordination mechanisms are important. Different levels of government often have different objectives, priorities and ways of working, which makes effective delivery of adult learning programmes challenging. Vertical co-ordination mechanisms can help national governments understand and respond to the specific skills needs of local areas, allow local actors to better understand and support national learning policies, address gaps in adult learning provision and support the sharing of local experiences (OECD, 2019[4]].

Many countries have taken steps to improve the co-ordination of adult learning systems across all levels of government. These includes pursuing collaborative partnerships across government levels and engaging in dialogue on the adjustment and transfer of responsibilities to lower levels of government. However, from the point of view of local governments, further co-ordination is important to develop in order to refine place-based skills development.

\section{Action 1.1 Develop partnerships across different levels of government}

Partnerships involving different levels of government are one tool for helping to improve this vertical co-ordination. Such partnerships can support the alignment of objectives based on a common understanding of the labour market context and local priorities. Partnerships may be more or less formalised, e.g. through contracts, agreements or skills pacts and may allow all parties to commit either to take action or to follow guidelines that ensure co-ordination of adult skills policies. In addition, they may be focused on the development and implementation of specific policies or be of a more general character covering several elements of the adult learning system (OECD, 2020[54]).

The main advantages of multi-level partnerships are that they are based on mutual agreement, do not require legislative change and are public and transparent. Yet, partnerships can also be costly to negotiate, implement and enforce, which is why they require substantive debate and agreement on common goals and benefits to be effective. The city of Gijon, Spain has developed the Youth Action Agency, which is based on a multi-level governance system that involves both national, regional and local level stakeholders (Box 26). 


\section{Box 26. Fighting youth unemployment through local partnerships in Gijon (Spain)}

Through the Youth Action Agency, Gijon provides different "education and skills" itineraries for 200 young people every year to include them in the local labour market. The agency was launched in 2014 and is founded partly by transfers from national/regional government and the city-level budget. The objective of the Youth Activation Agency is to foster collaboration among the main stakeholders working in employment, education and youth in the city and across different levels of government in order to fight youth unemployment and support young people aged 16-30 in their integration in the labour market. A key element of the agency is the multi-level and multi-stakeholder governance system, which involves stakeholders from the Regional Education Government and Regional Employment Government, the Youth Association and the Regional Employers Association. Through the involvement of these stakeholders, the programme is better able to reach young people, involve employers in the project (Regional Employers Associations), manage the presentations in secondary schools (Regional Education Government) and access the regional training offer (Regional Employment Government). Aligning the interests of these different stakeholders has been one of the main challenges to the implementation of the programme. It has required the city to take a strong leadership role in demonstrating, year after year, the benefits of the project.

Source: OECD/Eurocities survey on adult learning systems in cities and regions. For more information go to Future-proofing Adult Skills Systems in Cities: Case Studies - OECD.

For countries in the European Union, this type of co-ordination can also be supported by initiatives at the European level. In July 2020, the European Commission presented the European Skills Agenda for Sustainable Competitiveness, Social Fairness and Resilience, which sets out objectives for reand upskilling for the next five years. The Skills Agenda includes the European Pact for Skills, which seeks to support public and private organisations in creating sustainable multi-level governance and multi-stakeholder skills strategies and partnerships (Box 27).

\section{Box 27. The European Pact for Skills}

Through the Pact for Skills initiative, which was set up in November 2020, the European Commission invites public and private stakeholders and organisations to join forces and take concrete action to re- and upskill people in Europe. The Pact for Skills can be joined by individual companies or other private or public organisations, regional or local partnerships, and industrial ecosystems or cross-sectoral partnerships. In November 2021, more than 450 organisations from all EU Member States had signed up. Pact for Skills members commit to a charter to build quality and inclusive skills initiatives and work against discrimination and for equal opportunities. Moreover, all members are required to set out for their partnerships or organisations concrete targets on what they want to do to increase skills (e.g. train people in their sector, invest in re- and upskilling, develop new training programmes or promote the value of learning within the organisation or partnership). The European Pact for Skills also includes a call for support for Local Pacts for Skills, where cities and regions play a key role in co-ordinating efforts of employers and education and training organisations at the local level to set up new training programmes to match the demand for new skills in regional and local areas.

Source: (European Commission, 2021[55]). 
Action 1.2 Establish formal boards bringing together different levels of government

A more formal way to ensure co-ordination across levels of government is through multi-level governance boards or other types of co-ordination bodies. These bodies can be used to promote dialogue, co-operation and collaboration, build capacity, align interests and timing, and share good practices across levels of government over longer periods. The advantage of such bodies is that they often are relatively easy to establish, and can facilitate locally tailored solutions based on multi-level co-ordination. However, they require strong accountability mechanisms to ensure effective outcomes (OECD, 2018[56]). In the Netherlands, the National STEM (science, technology, engineering and mathematics) platform was set-up as the governing body co-ordinating the implementation of the Technology Pact signed in 2013, which seeks to reduce the shortage of technically trained staff in the country (Box 28).

\section{Box 28. The Technology Pact and the National STEM platform in the Netherlands}

In 2013, over 60 parties in the Netherlands, including ministries, education sectors, regions, industry and employer organisations, and labour unions, signed the National Technology Pact in an effort to structurally improve alignment between education and the technology job market, and reduce the shortage of technically trained staff. To support the regional coordination and implementation of the Pact, a multi-level governance body - the Dutch National STEM platform - was set up to enable multi-level co-operation between government, industry and education providers ("triple helix co-operation"). The 12 main objectives of the national Technology Pact cover the entire "talent pipeline", from primary education to the active labour market. To achieve its objectives, the Technology Pact relies on policy support and strategic co-ordination (rather than direct funding) through the National STEM platform. Programmes and objectives within the Pact are set at a national level, but implementation is regional (and often sub-regional), creating a strategic mix of "top-down" and "bottom-up" interventions. This approach results in targeted initiatives in various formats that respond to regional challenges, which are often translated into (sub-) regional pacts.

Source: (EU STEM Coalition, 2021 $\left.{ }_{[57]}\right)$ For more information go to Future-proofing Adult Skills Systems in Cities: Case Studies - OECD.

\section{Action 1.3 Engage in dialogue with national government on new competences}

Partnerships and boards are often an alternative to legal mechanisms (e.g. legislation, regulation and constitutional change), which divide responsibilities on a more long-term basis. There is no ideal policy model for the division of competences in adult learning systems and any act of decentralisation must always be well designed and aligned with other parts of the existing system. However, given the divergences in local skills needs, the devolution of responsibilities can be an important instrument to give local policy makers more flexibility to innovate and optimise the delivery of adult learning, better adjust national 
goals to particular local demands, and develop local partnership approaches based on local organisational strengths.

When deciding on how responsibilities are split, national and local governments together must seek to strike the right balance between national coherence, simplicity and accountability on the one hand and flexibility to align policies to local needs and favour innovative practices on the other. Moreover, they must ensure that the local circumstances are right (do local actors have the necessary capacities and resources to make use of decentralised responsibilities?) and that reforms are coherent (are objectives, measures and incentive structures in line with other parts of the system?) so as not to create further fragmentation in the system.

Since the early 2010s, changing governments in the United Kingdom have committed to devolve power to give cities and local areas greater control over skills and other public policies. This "localisation agenda" has been driven by the overarching aim to drive local economic growth and has resulted in increased flexibility for cities and local areas to create demand-led systems that support local jobs and growth (Clayton and McGough, 2015[58]). In London, the United Kingdom, for example, skills devolution has been ongoing since 2014 and was revitalised with the launch of the Skills for Londoners Strategy in 2018 (Box 29).

\section{Box 29. Greater London's Skills for Londoners Strategy (the United Kingdom)}

London is among the leading OECD cities in recognising skills as a fundamental driver of economic growth and resilience. The Greater London Authority (GLA), the governing body of Greater London, has made adult learning a priority with the development of the Skills for Londoners Strategy. The Skills for Londoners Strategy sets out the Mayor's vision to create a post-16 technical and vocational education and skills system that meets the needs of Londoners, based on the devolution of the Adult Education Budget to London.

In 2014, the GLA and London Councils proposed to the national government to undertake a skills devolution to London. Their proposal included suggestions on devolving skills funding, including the Adult Education Budget, London's share of advanced learner loans and a guaranteed "proportionate return" to London from the apprenticeship levy. Since then, London has continued to develop and articulate its vision for adult learning and skills, and to use available resources to put this into place, including with the launch of the Skills for Londoners Strategy in 2018. Within this skills strategy, the Mayor set out an ambition to seek significant devolution of skills funding - including careers information, advice and guidance, apprenticeships funding, and the UK Shared Prosperity Fund - in order to create "a single, integrated skills and adult education offer for London to deliver a more strategic, whole-system approach to post-16 skills." To support the implementation of the strategy, the London City Hall, London's boroughs and central government work together with London's businesses, skills and education providers to address the skills gap in the city.

Source: (OECD, 2021 ${ }_{[32])}$. 


\section{Key policy area 2: Strengthen co-ordination with local actors}

Within any given region or city, many different actors are involved delivering adult learning policies. These often include local government departments and authorities, public employment services, universities and schools, social partners, private training providers, and local businesses. All these actors have different responsibilities, pursue different goals, administer separate budgets, and often do not perceive themselves as being a part of a joint "system" (see Box 30). Alignment of interests among actors is unlikely to happen spontaneously; rather it requires effective co-ordination and co-ordination measures to decide who does what, when, how and why.

\section{Box 30. The actors involved in local adult learning systems and their different roles}

Public Employment Services (PES): PES often engage in the provision of career guidance services, training and education of unemployed or inactive adults in need of dedicated measures to develop their skills and improve their employability, and skills assessment and anticipation exercises.

Social partners: Social partners can be involved in the development, financing and monitoring of programmes and can also be providers of adult learning. While involvement often takes place at the national level, social partners are equally relevant at the local level where the implementation of programmes takes place.

Providers: Training and education providers include a range of actors, including public training institutes and schools, universities, private training institutes, civil society organisations, social partners, employers, etc. Strategic engagement of providers is necessary to ensure the alignment of skills supply with skills demand and to overcome barriers to participation - e.g. by adjusting the content, format and time of programmes to the need of specific groups or local skills demand.

Businesses: Businesses play a central role in adult learning systems not least as the main provider of non-formal adult learning and as a significant investor in training provision. In addition, involvement of employers in the design and implementation of adult learning programmes is important to ensure alignment of skills supply and demand.

Learners: Learners are at the core of adult learning as they are the ones participating in learning and training activities in order to strengthen their link to the labour market. Understanding the needs and motivations of learners is important to design adult learning systems and financing mechanisms that increase participation and learning outcomes for all.

NGOs, civil society organisation and social economy actors ${ }^{1}$ : These actors often engage in learning provision locally, including non-formal and community-based learning. They are often well placed to understand the skills and training needs of adults and to meet these needs through targeted programmes.

\footnotetext{
${ }^{1}$ The social economy includes associations, co-operatives, foundations, mutual organisations and social enterprises. The distinctive feature of the social economy is its focus on economic practices that are sustainable and inclusive (i) by addressing societal (i.e. social and/or environmental) needs; (ii) by organising economic activities building on local roots, as well as using participatory and democratic governance; and (iii) by working in close co-operation with other economic actors and relevant stakeholders (OECD, 2020[70]).
} 


\section{Action 2.1 Engage private actors in local skills partnerships}

Engaging with non-government stakeholders and collaborating through local skills partnerships is a vital tool for local governments to deal with the inherent complexities of adult learning systems. While co-operation may take many forms, from ad hoc and fragmented working arrangements to more formal relationships between relevant actors, well-functioning partnerships and local skills ecosystems are likely to be characterised by more formal and steady relationships (Finegold, $\left.1999_{[59]}\right)$ ). The term local skills ecosystem may be used to describe the dynamic network of interdependent actors which through their various interactions, roles, interests and resources shape the development, supply, demand and deployment of skills in any given industry or area (Anderson and Warhust, 2012[60]]). Skills ecosystems may develop organically, but often governments have attempted to emulate them via specific policy initiatives (OECD, 2020[54]).

The positive benefits of well-functioning local partnerships and skills ecosystems include:

- Providing valuable information to the policy-making and implementation process through experiences with the real-world effects of policies.

- Creating commitment and buy-in among relevant stakeholders to work towards a joined up local skills strategy.

- Mobilising and involving employers in the financing and provision of training.

- Ensuring that the training provided meets the demand of the local economy.

Yet, the development of partnerships and skills ecosystems can be very timeconsuming for local governments. Among the key challenges are identifying relevant actors and breaking down "silos" so to build up partnership models that are beneficial for all and perceived as legitimate in the local community (OECD, 2020[54]). In order to do so, it is important to develop a common language that co-operation can be based on and to have patience in the development of partnerships (learning how to co-operate always takes time). In Ghent, Belgium, the municipality is working on a pilot project - The House of Skills project - that aims to build a local ecosystem around lifelong learning in the city. Another example of a local skills partnership is found in Helsinki, Finland, where the municipality collaborates with Google (which has a local office in the city) to provide digital skills training to a broad range of citizens in the city (Box 31 ). 


\section{Box 31. Local Skills Partnerships to support local provision of adult skills}

\section{The House of Skills project in Ghent (Belgium)}

The City of Ghent is conducting two pilot projects to test the introduction of a House of Skills (first developed and implemented in Amsterdam, the Netherlands) that aims to increase sustainable employability especially for those with middle and lower education levels, in the context of rapidly changing labour markets, jobs and careers. The pilot projects run from September 2020 to the end of August 2022, and are financed by the European Social Fund (ESF), the City Council of Ghent and the Flemish regional government. The projects are based on a broad partnership of local stakeholders, including private companies such as Volvo Cars and Europabank, the Flemish public employment service VDAB, and the career guidance organisation KOPA. In addition, a stakeholder group has been created including sectoral training funds, the employers' federation Febelfin, representatives from the Flemish government, career guidance experts from RiseSmart, labour market experts from Agoria and education representation via the municipal department of education. The two pilot projects in Ghent focus specifically on 1) developing skills and supporting career transitions for employees in shrinking professions, and 2) employees who need further training because of a rapidly changing work environment. They also focus on how to develop more future-oriented skills, ensure continuous training and retraining of employees, and change the behaviour of every worker so that they more actively take control of their own career paths and realise that lifelong learning is essential for all.

\section{The City of Helsinki Collaborates with Google to Open a Digital Learning Space (Finland)}

In 2019, Google opened a learning space - the Google Digital Garage - in Helsinki. The main objective of the Google Digital Garage is to provide digital skills training free of charge to a broad range of people including jobseekers, entrepreneurs and students. The programme, jointly organised by Google and the City of Helsinki, is targeted at jobseekers who are interested in employment with social media, analytics and online advertising. In this programme, jobseekers receive a three-week digital marketing training in their interest area. Applications for the programme are made directly to the City of Helsinki. For SMEs, the learning space offers assistance in better utilizing digital tools in their businesses, through various courses and workshops. The learning space is part of the Grow with Google programmes, aimed at helping people, businesses and local communities gain digital skills for employment, as well as career and business growth. In addition to the learning space, the Digital Garage offers free online courses, which are open to everybody in the city. The Google Digital Garage and the Grow with Google programmes also exist in other countries, including the United Kingdom and France.

Source: OECD/Eurocities survey on adult learning systems in cities and regions. For more information go to Future-proofing Adult Skills Systems in Cities: Case Studies - OECD.

\section{Action 2.2 Work with neighbouring municipalities}

Cities can also look beyond their own administrative boundaries in developing partnerships by working with neighbouring municipalities or regions. Such partnerships have a number of potential benefits, such as joint development of skills assessment and anticipation exercises where there are common interests. They can also improve strategies to align local supply with demand and help to maximise synergies with other policy areas and funding pools, e.g. by ensuring that funding targeted to regional development takes into account local skills needs. 
In addition, they may enable local governments to pool resources and ensure stronger and broader roll-out of programmes (OECD, 2018[56]). One of the difficulties arising when establishing such partnerships may be to agree on a good leadership model and to ensure continued engagement among all partners. Examples of partnerships across municipalities are the Career Path Värmland programme implemented in 11 municipalities in the region of Värmland, Sweden, and the cross-municipality programme to tackle functional illiteracy in the region of Hart van Brabant, the Netherlands (Box 32).

\section{Box 32. Partnerships across municipalities and regions}

\section{The Career Path Värmland Programme in Karlstad (Sweden)}

The Career Path Värmland (Yerkesväg Värmland) programme is implemented in 11 municipalities in the region of Värmland in Sweden. The region of Värmland is facing major challenges related to the supply of competences due to, among other things, a declining population base, demographic challenges and high unemployment especially among foreignborn. The objective of the programme is to provide targeted career guidance combined with vocational training for groups with weak language skills. The programme runs from August 2020 to June 2022, and is funded by the local governments and the European Social Fund (ESF). The programme is based on the fundamental principle that cross-sectoral co-operation and integrated perspectives and efforts are needed to overcome ongoing labour market challenges. Through the programme, conditions for cross-sectoral collaboration between employers and industries with recruitment needs, the local Public Employment Offices, adult education and labour market and integration services, among others, have been developed. In addition, regional and inter-municipal collaboration is a key element of the project, as individual actors and municipalities often lack the resources and prerequisites to develop the necessary interventions and methods on their own. All participating municipalities have themselves chosen to be a part of the programme and have chosen their own focus. The Country Administration Board is primarily responsible for the project. The board co-ordinates the project with the participating municipalities and reports back to the ESF.

\section{Tackling Functional Illiteracy in the Region of Hart van Brabant (the Netherlands)}

In the region Hart van Brabant in the Netherlands, a significant number of inhabitants are struggling with functional illiteracy, which means that their reading and writing skills are inadequate to manage daily living and employment tasks that require reading skills beyond basic level. To overcome challenges with functional illiteracy, the Hart van Brabant region in the Netherlands has set out to motivate their inhabitants to tackle the problem in an accessible way through the programme "Approach functional illiteracy: together we can understand each other" (Aanpak laaggeletterdheid "samen begrijpen wij elkaar"). As part of the programme, students are offered basic skills programmes (reading, writing and language courses) that take place in small groups, at their own pace, at a place near to them and at different times of the day (both day and evening courses). It is possible to sign up for courses all year round, and intake interviews take place before signing up to make sure that the offer is tailored to the need of the student. Tilburg is the central municipality in the region of Hart van Brabant and therefore has the overall and final responsibility for implementing the programme in the region.

Source: OECD/Eurocities survey on adult learning systems in cities and regions. For more information go to Future-proofing Adult Skills Systems in Cities: Case Studies - OECD. 
Such partnerships can also extend to other types of peer regions or cities to promote mutual learning. For example, to build up the concept of Regional Skills Ecosystems, six regions (Basque Country, Brittany, Catalonia, Tuscany, Varazdin, and Vestland) across five European countries have started the S4Stride Project. The project is co-ordinated by the European Association of Regional and Local Authorities for Lifelong Learning (EARLALL) and aims to improve regional capacities to identify skills needs and adapt training provisions accordingly. It is based on the idea that strong skills ecosystems must be based on engagements of four main types of stakeholders: public authorities, education centres, companies and individuals. Furthermore, the project is based on the belief that a regional perspective for skills challenges is of utmost importance to tackle the new opportunities that industry 4.0, the Sustainable Development Goals and soft skills are already opening (\#S4Stride, 2021[61]).

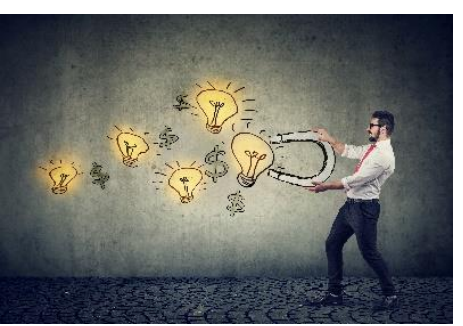

\section{Key policy area 3: Develop coherent financing models at all levels of government}

The financing model influences the quality and quantity of adult learning programmes, the behaviour and choice of providers, individuals and businesses, and the ability of local skills systems to match the local demand for skills (see Chapter 2). In learning systems where decision-making powers are divided between levels of government, not least the alignment of decision-making and financing responsibilities as well as the simplicity of the overall system is important for the ability of local governments to adjust the provision of adult learning to local needs. While many decisions on financing tend to be taken at the national level, there are still possibilities for local governments to engage in dialogue on the financial structures in place and to develop local skills financing pacts to strengthen the funding available at local level.

\section{Action 3.1 Negotiate flexible financing arrangements with higher} levels of government

For local practitioners, the alignment of decision-making and financing responsibilities is crucial for their ability to put in place policies that work. Yet, there are many examples where financing responsibilities and incentive structures are not well-aligned resulting in either over- or underspending on adult learning policies or in investments that do not support local skills needs. Local governments may engage in dialogue with national governments on the alignment of financial incentives and the possible use of more flexible funding structures such as bilateral agreements or continuously negotiated funding contracts. Examples of how funding is allocated to lower levels of government through such bilateral agreements can be found in Canada and France (Box 33). 


\section{Box 33. Funding contracts and agreements}

In Canada, the federal government uses bilateral agreements between federal government, provinces and territories to allocate large amounts of annual funding to lower levels of government in the area of adult learning. The bilateral agreements stipulate the agreed-upon objectives that the funding should achieve and establish key features of the programmes to be delivered. However, they also leave a high degree of flexibility to each provincial or territorial government to adjust programmes to meet the specific needs of their adult population.

In France, the national government uses six-year contracts to set out funding flows from the central state and the regions to adult learning policies. The contracts are based on agreedupon objectives that cut across a range of policy priorities, including infrastructure, higher education, environmental policy, digital economy, territorial development and employment.

Source: (OECD, 2018[56]).

\section{Action 3.2 Develop local skills financing pacts between local}

\section{stakeholders}

The possible benefits from investment in adult learning are distributed among the public, individuals and businesses, but the incentives for these actors to invest in skills development are not always clear. For individuals, there is a risk of underinvestment in education and training due to competing short-term pressing needs or a lack of up-to-date information on the demand for skills. For businesses, there is a risk of overinvestment in specific skills that have immediate pay-offs in terms of productivity and underinvestment in more generic skills that are more multifaceted and more easily transferable to other parts of the labour market (Becker, 1993[62]).

Local skills financing pacts, signed by government actors as well as other stakeholders such as social partners, employers and training providers, can help overcome some of these challenges. Such pacts can lay out the respective roles of various actors in the financing of adult learning, the types of priority initiatives to be funded, the types of entities eligible for funding, criteria and procedures for allocating funding to eligible entities, provisions to ensure funding to cover the delivery of programmes and administrative costs, etc. (OECD, 2018[56]). In Sheffield, the United Kingdom, the city has through several devolution agreements taken greater control of local skills funding, which has resulted in the development of a local tripartite funding model (Box 34). 


\section{Box 34. The Sheffield City Regions' Employment and Skills Partnership}

As part of a broader national agenda to devolve various aspects of employment and skills policies to local areas from 2010 to 2015, the Sheffield City Region Devolution Agreement was signed in December 2014. The purpose of the devolution agreement was to create a more effective demand-led local employment and skills system across the UK. In the Sheffield City Region, among other things, this resulted in the devolution of GBP 28 million in Adult Skills Budget funding, contributing towards a local tripartite funding model including employer and city region local authority contributions. Evaluations of devolution agreements have shown that the greater control over local skills delivery and funding allocations have provided strong incentives to bring together all partners to fill in gaps in national provision, and experiment with new projects and types of funding. In Sheffield, the processes enabled a scaling-up of partnership activities that prompted the reformation of the Sheffield City Council Employment and Skills Board. The opportunity to shape the skills system with additional funding available made it more attractive and worthwhile for local partners - including representatives from strategic sectors such as manufacturing and engineering, large employers in hospitality, the SFA and Sheffield College - to work together at city level.

Building on this previous work and in the context of the COVID-19 crisis, the Sheffield City Region has recently developed a new Regional Post-18 Education Partnership. The purpose of the partnership is to identify positive and practical actions which can impact the most disadvantaged young people and adults in the region as they enter the post- 18 system through education or work. The partnership brings together leaders from the region's further and higher education providers, the Sheffield City Region Local Enterprise Partnership, the Confederation of British Industry and the Higher Education Progression Partnership.

Source: (Clayton and McGough, 2015[58]). 


\section{References}

\#S4Stride (2021), \#S4Stride - Exchanging best practices to foster regional skills intelligence strategies in Europe in four steps, https://s4stride.eu/ (accessed on 1 October 2021).

Adalet McGowan, M. and D. Andrews (2015), "Labour Market Mismatch and Labour Productivity: Evidence from PIAAC Data", OECD Economics Department Working Papers, No. 1209, OECD Publishing, Paris.

Anderson, P. and C. Warhust (2012), "Lost In Translation: Skills policy and the shift to skill ecosystems", in Dolphin, T. and D. Nash (eds.), Complex New World: Translating new economic thinking into public policy, IPPR, London.

Becker, G. (1993), Human Capital: A Theoretical and Empirical Analysis with Special Reference to Education, University of Chicago Press, Chicago.

Berube, A. and N. Bateman (2020), Who are the workers already impacted by the COVID-19 recession?.

Burning Glass (2019), Excelsior 2018-2020, https://www.burningglass.eu/en/excelsior-2018-2020/ (accessed on 4 October 2021).

Cedefop (2017), "Investing in skills pay off: the economic and social costs of low-skilled adults in the EU", Cedefop research apper, No. 60 , Cedefop, Luxembourg: Publications Office.

Cedefop, European Commission and ICF (2019), European inventory on validation of non-formal and informal learning 2018 update: Synthesis report, http://libserver.cedefop.europa.eu/vetelib/2019/european inventory vali dation 2018 synthesis.pdf (accessed on 19 November 2021).

City of Helsinki (2021), Google opens Digital Garage learning space in Helsinki, https://www.hel.fi/uutiset/en/kaupunginkanslia/google-opensdigital-garage-learning-space-in-helsinki (accessed on 4 October 2021).

Clayton, N. and L. McGough (2015), City deals and skills: How have City and Local Growth Deals supported the development of employment and skills policies that reflect local demand?, Centre For Cities.

Department of Further and Higher Education, R. (2022), Regional Skills Partnership for Skills, https://www.regionalskills.ie/ (accessed on 25 January 2022).

Dimitrova, A. (2019), Amsterdam open first IT training centre for vulnerable people, http://www.themayor.eu/en/amsterdam-opens-first-it-trainingcentre-for-vulnerable-people (accessed on 1 October 2021). 
DNAsix (2021), Southampton City Council launches digital skills pilot, https://www.dnasix.com/blog/southampton-city-council-launches-digitalskills-pilot (accessed on 4 October 2021).

EU STEM Coalition (2021), "Techniepact (Technology Pact)", https://www.stemcoalition.eu/programmes/techniekpact-technology-pact (accessed on 1 October 2021).

Eurocities (2021), Vienna - Education and training for young people, https://covidnews. eurocities.eu/2020/06/10/vienna-education-andtraining-for-young-people/ (accessed on 1 October 2021).

European Association for the Education of Adults (2021), European Association for the Education of Adults, https://eaea.org/ (accessed on 1 October 2021).

European Commission (2021), Pact for Skills - Directorate for Employment, Social Affairs and Inclusion, https://ec.europa.eu/social/main.jsp?catld=1517\&langld=en (accessed on 1 October 2021).

European Commission (2021), WISE - Giving women in Donegal, Ireland, the skills and confidence to return to the labour market, https://www.greatermanchester-ca.gov.uk/what-we-do/work-and-skills/ (accessed on 1 October 2021).

European Commission (2015), An in-depth analysis of adult learning policies and their effectiveness in Europe, Directorate General for Employment, Social Affairs and Inclusion.

Finegold, D. (1999), "Creating self-sustaining high-skill ecosystems", Oxford [59] Review of Economic Policy, Vol. 15/1, pp. 60-81.

Fundación Adsis (n.d.), The Circular Economy: Jobs for the Future, https://www.fundacionadsis.org/es/madrid/proyectos/economia-circularempleos-de-futuro (accessed on 23 January 2022).

Glasgow Guarantee (2021), MAKE IT WORK AND GET RECRUITING, https://www.glasgowguarantee.org/ (accessed on 4 October 2021).

GMCA (2021), Work and Skills - Greater Manchester Combined Authority, https://www.greatermanchester-ca.gov.uk/what-we-do/work-and-skills/ (accessed on 1 October 2021).

Green Connect (2021), What we do, https://green-connect.com.au/whatwe-do/ (accessed on 4 October 2021).

Humber Local Enterprise Partnership (2021), Skills Pledge, https://www.humberlep.org/skills-pledge/ (accessed on 4 October 2021).

Kato, S., V. Galán-Muros and T. Weko (2020), "The Emergence of Alternative Credentials", OECD Education Working Paper, No. 216, OECD, Paris.

Michigan Works! Southwest (2021), Employment Hubs, 
https://www.michiganworkssouthwest.org/other-services/employmenthubs/ (accessed on 20 January 2022).

Montt, G. (2015), "The causes and consequences of field-of-study mismatch: An analysis using PIAAC", OECD Social, Employment and Migration Working Papers, No. 167, OECD Publishing, Paris.

New South Wales Department of Education and Training (2008), A guide to [64] the skill ecosystem approach to workforce development, NSW Department of Education and Training, Sydney.

OECD (2021), Career Guidance for Adults in a Changing World of Work, Getting Skills Right, OECD Publishing, Paris, https://dx.doi.org/10.1787/9a94bfad-en.

OECD (2021), Future-Proofing Adult Learning in London, United Kingdom, OECD Reviews on Local Job Creation, OECD Publishing, Paris, https://dx.doi.org/10.1787/c546014a-en.

OECD (2021), "Micro-credential innovations in higher education: Who, What and Why?", OECD Education Policy Perspectives, No. 39, OECD, Paris.

OECD (2021), "Multi-level governance of active labour market policies", OECD, Paris.

OECD (2021), OECD Employment Outlook 2021: Navigating the COVID-19 Crisis and Recovery, OECD Publishing, Paris, https://dx.doi.org/10.1787/5a700c4b-en.

OECD (2021), OECD Skills Outlook 2021: Learning for Life, OECD Publishing, Paris, https://dx.doi.org/10.1787/0ae365b4-en.

OECD (2020), "COVID-19: Protecting people and societies.", OECD, Paris.

OECD (2020), "Education responses to COVID-19: Embracing digital learning and online collaboration", OECD, Paris.

OECD (2020), Job Creation and Local Economic Development 2020: Rebuilding Better, OECD Publishing, Paris, https://dx.doi.org/10.1787/b02b2f39-en.

OECD (2020), OECD Employment Outlook 2020: Worker Security and the COVID-19 Crisis, OECD Publishing, Paris, https://dx.doi.org/10.1787/1686c758-en.

OECD (2020), "Social economy and the COVID-19 crisis: current and future roles”, OECD, Paris.

OECD (2020), Strengthening the Governance of Skills Systems: Lessons from Six OECD Countries, OECD Skills Studies, OECD Publishing, Paris, https://dx.doi.org/10.1787/3a4bb6ea-en.

OECD (2020), Who Cares? Attracting and Retaining Care Workers for the Elderly, OECD Health Policy Studies, OECD Publishing, Paris, 
https://dx.doi.org/10.1787/92c0ef68-en.

OECD (2019), Getting Skills Right Engaging low-skilled adults in learning, http://www.oecd.org/employment/emp/ engaging-low-skilled-adults2019.pdf (accessed on 10 June 2021).

OECD (2019), Getting Skills Right Engaging low-skilled adults in learning, http://www.oecd.org/employment/emp/.

OECD (2019), Getting Skills Right: Future-Ready Adult Learning Systems, Getting Skills Right, OECD Publishing, Paris, https://dx.doi.org/10.1787/9789264311756-en.

OECD (2019), OECD Employment Outlook 2019: The Future of Work, OECD Publishing, Paris, https://dx.doi.org/10.1787/9ee00155-en.

OECD (2019), OECD Skills Outlook 2019 : Thriving in a Digital World, OECD Publishing, Paris, https://dx.doi.org/10.1787/df80bc12-en.

OECD (2018), Job Creation and Local Economic Development 2018: Preparing for the Future of Work, OECD Publishing, Paris, https://dx.doi.org/10.1787/9789264305342-en.

OECD (2018), Skills Strategy Implementation Guidance for Portugal: Strengthening the Adult-Learning System, OECD Skills Studies, OECD Publishing, Paris, https://dx.doi.org/10.1787/9789264298705-en.

OECD (2017), Financial Incentives for Steering Education and Training, Getting Skills Right, OECD Publishing, Paris, https://dx.doi.org/10.1787/9789264272415-en.

OECD (2016), Getting Skills Right: Assessing and Anticipating Changing Skill Needs, OECD Publishing, Paris.

OECD (2015), Integrating Social Services for Vulnerable Groups: Bridging Sectors for Better Service Delivery, OECD Publishing, Paris, https://dx.doi.org/10.1787/9789264233775-en.

OECD (2014), OECD Employment Outlook 2014, OECD Publishing, Paris, https://dx.doi.org/10.1787/empl outlook-2014-en.

OECD (2012), Better Skills, Better Jobs, Better Lives: A Strategic Approach to Skills Policies, OECD Publishing, Paris, https://dx.doi.org/10.1787/9789264177338-en.

OECD (2004), Career guidance and public policy : bridging the gap., Organisation for Economic Co-operation and Development.

OECD (2001), Education Policy Analysis 2001, OECD Publishing, Paris, https://dx.doi.org/10.1787/epa-2001-en.

OECD/European Union (2019), The Missing Entrepreneurs 2019: Policies for Inclusive Entrepreneurship, OECD Publishing, Paris, https://dx.doi.org/10.1787/3ed84801-en. 
OECD/UCLG (2019), 2019 Report World Observatory on Subnational

Government Finance and Investment - Key Findings, https://www.sngwofi.org/reports/Key Findings 2019.pdf (accessed on 24 September 2021).

Robson, J. (2022), Micro-credentials: The new frontier of adult education and training, https://www.oecd-forum.org/posts/micro-credentials-thenew-frontier-of-adult-education-and-training (accessed on 23 January 2022).

Shah, C. and G. Burke (2010), "Skills shortages: Concepts, measurement and policy responses", in International Encyclopedia of Education, http://dx.doi.org/10.1016/B978-0-08-044894-7.00778-8.

theMayor.eu (2020), Rotterdam retrains jobseekers to make them fit for the new economic reality, https://www.themayor.eu/fr/a/view/rotterdamretrains-jobseekers-to-make-them-fit-for-the-new-economic-reality-5819 (accessed on 4 October 2021).

Tough, A. and M. Knowles (1985), "Andragogy in Action: Applying Modern Principles of Adult Learning", The Journal of Higher Education, Vol. 56/6, http://dx.doi.org/10.2307/1981081.

UIA (2019), MILMA Project - Migrants Labour Integration Model based on Acculturation Project, http://www.uia-initiative.eu/en/uiacities/fuenlabrada (accessed on 1 October 2021).

URBACT (2017), So stay hotel: A socially responsible hotel to train young people leaving foster care for adult life - Gdansk/Poland, https://urbact.eu/so-stay-hotel (accessed on 1 October 2021).

Urban Innovation Action (2021), Aveiro Steam City, https://uiainitiative.eu/en/uia-cities/aveiro (accessed on 4 October 2021).

Urban Innovative Actions, U. (2021), Urban Innovative Actions - Vantaa: Jobs and Skills in the local economy, https://uia-initiative.eu/en/uiacities/vantaa.

Werquin, P. (2010), Recognising Non-Formal and Informal Learning: Outcomes, Policies and Practices, OECD Publishing, Paris, https://dx.doi.org/10.1787/9789264063853-en.

Wilson, R. and A. Zukersteinova (2011), Anticipating changing skill needs: A Master Class, New Skills Network Event, Budapet.

Windisch, H. (2015), "Adults with low literacy and numeracy skills: A literature review on policy intervention", OECD Education Working Papers, No. 123, OECD Publishing, Paris.

Workforce Planning Board Ontario (2021), Champions of Ontario's Local Labour Market Solutions, http://www.workforceplanningontario.ca/en/ (accessed on 4 October 2021). 
Local Employment and Economic Development (LEED) Programme

Centre for Entrepreneurship, SMEs, Regions and Cities www.oecd.org/cfe/leed

\section{a) $\mathrm{OECD}$}

